\author{
Contato \\ Rua Areal de Baixo \\ 40060-210 - Salvador - Bahia \\ lisa.earl.castillo@gmail.com
}

\section{O TERREIRO \\ DO GANTOIS: REDES SOCIAIS E ETNOGRAFIA HISTÓRICA NO SÉCULO XIX*}

\author{
Lisa Earl Castillo** \\ Universidade Estadual de Campinas \\ Campinas - São Paulo - Brasil
}

\title{
Resumo
}

O Ilê Iyá Omi Axé Iyamassé, localizado na cidade de Salvador e mais conhecido como o Terreiro do Gantois, é um dos mais antigos candomblés da Bahia, comentado nos estudos afro-brasileiros desde os tempos de Nina Rodrigues e reconhecido como patrimônio histórico do Brasil desde 2002. Contudo, pouco se sabe sobre seus primeiros tempos, além de tradições orais sobre o envolvimento da fundadora no legendário Candomblé da Barroquinha. Este texto cruza dados das tradições orais com pesquisa documental e etnográfica, reconstruindo assim as histórias de vida da fundadora, Maria Júlia da Conceição, e de seu marido, Francisco Nazareth d'Etra, desde o cativeiro até a liberdade. A fundadora era de nação nagô, mas seu marido era jeje e as evidências sobre os primeiros tempos da comunidade religiosa apontam para a importância de influências jejes. O texto ainda traz novas reflexões sobre a antiga relação entre o Gantois e o Ilê Axé Iyá Nassô Oká (Casa Branca), sugerindo uma nova cronologia para a cisão entre as duas comunidades.

\section{Palavras-chave}

Candomblé da Bahia - africanos libertos - barbeiros - irmandades negras - sincretismo.

A pesquisa teve o apoio de uma bolsa de pós-doutorado da Fundação de Apoio à Pesquisa do Estado de São Paulo - Fapesp. Minha gratidão aos descendentes de Maria Júlia da Conceição e Francisco Nazareth, especialmente à ialorixá Carmen Oliveira, pelo diálogo; a Urano Andrade, Luis Nicolau Parés, Ângela Lühning e Carlos da Silva Jr., pelos documentos compartilhados; a João José Reis, Kristin Mann, Sílvia Lara, Mariza de Carvalho Soares, Hendrik Kraay, Willys de Andrade Santos e os membros de duas linhas de pesquisa, História Social da Cultura (Unicamp) e Escravidão e Invenção da Liberdade (Ufba), pelas críticas a versões iniciais deste texto.

* Doutora em Letras pela Universidade Federal da Bahia e bolsista de pós-doutorado do Centro de Pesquisa em História Social da Cultura - Cecult-Unicamp. 


\author{
Contact \\ Rua Areal de Baixo \\ 40060-2 10 - Salvador - Bahia \\ lisa.earl.castillo@gmail.com
}

\section{SOCIAL NETWORKS}

AND HISTORICAL

ETHNOGRAPHY

OF THE GANTOIS

TERREIRO IN THE

NINETEENTH

CENTURY

\author{
Lisa Earl Castillo
}

Universidade Estadual de Campinas

Campinas - São Paulo - Brazil

\begin{abstract}
The terreiro Ilê Iyá Omi Axé Iyamassé, located in the city of Salvador and better known as the Gantois, is one of the oldest candomblé houses in the city of Salvador, Bahia. In Afro-Brazilian studies, the terreiro has been commented on since the early works of Nina Rodrigues and in 2002 it gained national historic landmark status. However, little is known about its early days, aside from oral traditions that its founder was involved in a legendary temple located in the Barroquinha district. This paper analyzes oral traditions in conjunction with ethnographic and archival data in reconstructing the lives of the founding priestess, Maria Júlia da Conceição and her husband, Francisco Nazareth d'Etra, from capitivity to freedom. Although the founder was a Yoruba speaker, her husband was Jeje and the evidence suggests that Jeje influences were important in the religious community's early days. The paper also reflects over the nature of the Gantois's ties to Ilê Axé Iyá Nassô Oká (Casa Branca), offering a new chronology for the moment of separation between the two communities.
\end{abstract}

\title{
Keywords
}

Bahian Candomblé-African freedmen-barbers-blackbrotherhoods-syncretism 
O Ilê Iyá Omi Axé Iyamassé, ou o Terreiro do Gantois, como é mais conhecido, é um dos mais antigos candomblés da Bahia. Tombado pelo Instituto de Patrimônio Histórico e Artístico Nacional (IPHAN), em 2002, o Gantois tem destacada importância desde o início dos estudos sobre as religiões afro-brasileiras. Numa série de artigos publicados em 1896, Nina Rodrigues, o pioneiro desse campo acadêmico, tomava o terreiro como modelo "para uma ideia exata de que é um templo fetichista na Bahia". ${ }^{1}$ Naquele tempo, a casa ainda era liderada pela fundadora, a velha africana Maria Júlia da Conceição, com o auxílio de uma filha, Pulquéria. Em 1917, o Gantois voltou à cena etnográfica, no trabalho do intelectual e ativista negro Manuel Querino, ele mesmo membro da comunidade religiosa.

Nesse ínterim, Maria Júlia havia falecido, sendo substituída por Pulquéria. Segundo a tradição oral, Maria Júlia e seu marido, um jeje liberto chamado Francisco Nazaré de Eta, tiveram sete outros filhos, entre eles uma filha chamada Damiana, cuja neta, Escolástica, foi a terceira ialorixá. Conhecida como Mãe Menininha, ela permaneceu no cargo por mais de seis décadas, tornando-se uma personagem célebre, tanto no âmbito religioso quanto no imaginário popular, atraindo intelectuais e músicos nacionalmente conhecidos ao terreiro. Depois de sua morte em 1986, Menininha foi sucedida pela mais velha de suas duas filhas, Cleuza. Com o falecimento de Mãe Cleuza em 1998, a irmã caçula, Carmen, se tornou a quarta ialorixá, cargo que ocupa até hoje. ${ }^{2}$

Apesar do reconhecido prestígio etnográfico do Gantois e da fama mais ampla que o terreiro alcançou nos tempos de Mãe Menininha, pouco se sabe sobre seus primeiros tempos. A narrativa mais conhecida, registrada pelo etnógrafo Edison Carneiro, afirma que a fundadora do Gantois era filha de santo de outro terreiro histórico, a Casa Branca do Engenho Velho, mas, depois da morte de Marcelina da Silva (Obatossi), ialorixá desta casa, Maria Júlia se afastou em decorrência de divisões internas sobre a sucessão, fundando em seguida seu próprio terreiro. Essa versão dos fatos, registrada

\footnotetext{
1 Cf. RODRIGUES, Nina. O animismo fetichista dos negros baianos. Rio de Janeiro: Biblioteca Nacional, 2006 [1996], p. 51.

2 Cf. QUERINO, Manuel. A raça africana e seus costumes na Bahia. Salvador: Empresa Gráfica da Bahia, 1917; entrevista com Carmen Oliveira, Salvador, 3/9/2013; NÓBREGA, Cida \& ECHEVERRÍA, Regina. Mãe Menininha do Gantois: uma biografia. Salvador: Corrupio, 2006, p. 12-13. Sobre Mãe Menininha, cf. também SANTOS, Jocélio Teles dos. Menininha do Gantois: a sacralização do poder. In: SILVA, Vagner Gonçalves da (org.). Caminhos da alma. São Paulo: Selo Negro, 2002, p. 133-152. (Memória afro-brasileira, v. 1).
} 
em 1948, tem sido reproduzida por gerações de pesquisadores e pela mídia, tornando-se pedra fundamental no imaginário popular sobre o candomblé.

Contudo, essa narrativa foi sempre contestada por Mãe Menininha, que afirmava ter sido sua bisavó "irmã de santo, e não filha de santo, de Marcelina Obatossi". Segundo Menininha, o Gantois não descende do Engenho Velho. Pelo contrário, os dois terreiros seriam galhos do mesmo tronco, compartilhando uma origem em comum: uma comunidade religiosa primordial, localizada no centro da cidade, num distrito conhecido como a Barroquinha. Depois da morte de Menininha, foram encontrados dois documentos que respaldaram seus argumentos: o primeiro, o testamento de Marcelina da Silva, revela que ela faleceu em 1885; o outro, uma matéria de jornal de 1868, comenta sobre o candomblé de "tia Júlia" e de sua filha Pulquéria. Assim, fica claro que a fundação do Gantois antecedeu, por mais de quinze anos, o falecimento de Marcelina da Silva. ${ }^{3}$

A partir dessa constatação, realizei um levantamento documental e etnográfico com o objetivo de rastrear a trajetória de Maria Júlia e seu terreiro e de matizar a natureza da relação com a Casa Branca. Os dados encontrados vislumbram os caminhos percorridos por Maria Júlia e Francisco Nazareth, desde o cativeiro até a liberdade, revelando a importância fundamental da rede social do marido, constituída principalmente por barbeiros africanos envolvidos em confrarias negras. Embora as fontes documentais não confirmem a cisão posterior entre o Gantois e a Casa Branca, elas apontam para dois indivíduos que transitavam entre as duas comunidades. Essas informações, em cruzamento com dados etnográficos, sugerem a fundação do terreiro por volta de 1850 . Este artigo ainda examina evidências documentais e etnográficas sobre as influências jejes na trajetória do Gantois, refletindo sobre as memórias de uma relação histórica com um importante terreiro de nação jeje, o Bogum.

\footnotetext{
Cf. CARNEIRO, Edison. Candomblés da Bahia. Rio de Janeiro: Civilização Brasileira, 1991, p. 56; VERGER, Pierre. Orixás. Salvador: Corrupio, 2003. p. 29-30; OLIVEIRA, Maria Inês Cortes de. $O$ liberto: seu mundo e os outros. São Paulo: Corrupio, 1988; SANTOS, Jocélio Teles dos. Menininha do Gantois: a sacralização do poder. In: SILVA, Vagner Gonçalves da (org.). Caminhos da alma. São Paulo: Selo Negro, 2002, p. 134. (Memória afro-brasileira, vol. 1). As contradições entre a versão de Carneiro e a tradição oral do Gantois já foram apontadas em BUTLER, Kim D. Freedoms given, freedoms won. New Brunswick: Rutgers University Press, 1998, p. 194.
} 


\section{O cruzamento de tradições orais e fontes escritas: alguns problemas metodológicos}

As tradições orais são fontes ricas para pesquisa histórica, mas ao mesmo tempo impõem desafios interpretativos, um assunto que suscitou bastante discussão nos campos da Antropologia e da História da África. No caso do candomblé, narrativas orais sobre os primeiros tempos dos terreiros guardam os nomes dos ancestrais fundadores, os quais fornecem pontos de partida para pesquisa documental, através da metodologia de "ligação nominativa". Nessa abordagem, o pesquisador procura os nomes em diversas fontes, cruzando as informações obtidas para assim reconstruir trajetórias individuais de vida. Nos últimos anos, a metodologia tem proporcionado novas perspectivas sobre as vidas de pessoas que vivenciaram o cativeiro, inclusive personagens do candomblé. ${ }^{4}$

As tradições orais do candomblé, contudo, apresentam algumas dificuldades específicas. Primeiro, elas tendem a enfatizar a atuação das mulheres, enquanto nos documentos oitocentistas quem se destaca são os homens. Outro problema diz respeito ao âmbito ritual: na memória oral, filiação espiritual e funções religiosas são centrais, enquanto na maioria das fontes escritas, são invisíveis ou quase isso em consequência do histórico de repressão e preconceito contra a religiosidade afro-brasileira. No que tange às primeiras gerações de ancestrais - aqueles nascidos na África -, ainda outro enigma é a dupla nomeação: os nomes adquiridos no cativeiro são menos lembrados do que os nomes africanos, mas estes quase nunca aparecem na documentação. Portanto, ao tentar preencher as lacunas nas tradições orais com informações proporcionadas por documentos históricos, é preciso proceder com extrema cautela, para não misturar por engano personagens que aparecem nos documentos, mas que não fazem parte da história do terreiro analisado.

\footnotetext{
4 Cf. VANSINA, Jan. Oral tradition as history. Oxford: James Currey, 1985; GINZBURG, Carlo $\mathcal{E}$ PONI, Carlo. O nome e o como: troca desigual e mercado historiográfico. In: GINZBURG, Carlo et al. A micro-história e outros ensaios. Rio de Janeiro: Bertrand, 1989, p. 169-178. Para exemplos de estudos que utilizam ligação nominativa para reconstruir as histórias de vida de libertos, ver, entre outros, REIS, João José. Domingos Sodré, um sacerdote africano: escravidão, liberdade e candomblé na Bahia do século XIX. São Paulo: Companhia das Letras, 2008; FERREIRA, Jackson André da Silva. Gurgalha: um coronel e seus dependentes no sertão baiano (Morro do Chapéu, século XIX). Tese de Doutorado, História Social, Universidade Federal da Bahia, Salvador, Bahia, 2014; CASTILLO, Lisa Earl $\mathcal{E}$ PARÉS, Luis Nicolau. Marcelina da Silva e seu mundo: novos dados para uma historiografia do candomblé ketu. Afro-Ásia, Salvador, n. 36, 2007, p. 111-151; SCOTT, Rebecca E HÉBRARD, Jean. Provas de liberdade: uma odisseia atlântica na era da emancipação. Campinas: Unicamp, 2014.
} 
Ainda outro fator que precisa ser levado em conta é a plasticidade da memória oral. Como alerta o antropólogo Jan Vansina, tradições orais proporcionam dados valiosos, mas são interpretações do passado. ${ }^{5}$ Ao longo das gerações, vão se transformando, através de omissões, inclusões e substituições, as quais frequentemente resultam em uma narrativa em que os fatos são representados de forma muito mais metafórica do que literal. Mudanças também podem ser introduzidas pelos pesquisadores que registram as tradições orais, por falhas de memória ou mesmo de entendimento. Enfim, apesar do valor desses textos orais, sua análise exige certo "jogo de cintura". Como no caso de fontes escritas, é preciso dar credibilidade e ao mesmo tempo manter uma visão crítica.

O primeiro documento que abriu caminhos para esta pesquisa foi um registro paroquial. Na Freguesia da Conceição da Praia, em 10 de dezembro de 1820, no batismo de uma escrava africana chamada Joanna, o padrinho foi um certo Francisco Nazareth de Etra, de nação jeje. Apesar da pequena diferença ortográfica no sobrenome ("Etra" em vez de "Eta"), ficou claro que era o mesmo homem lembrado como marido da fundadora do Gantois. O padrinho era escravo do mesmo senhor que a afilhada, um preto forro chamado José Antônio de Etra.

Três décadas depois, em 14 de maio de 1853, já liberto e maior de 50 anos, Francisco Nazareth de Etra se casou, na mesma freguesia, com uma africana liberta de prenome Júlia, a quem o pároco dava 40 anos de idade. Só podia ser a fundadora do Gantois, mas seu sobrenome não era Conceição. Era Soares de Sá. ${ }^{6}$ Essa discrepância com a tradição oral - muito mais significativa que a pequena variação ortográfica no sobrenome do marido - me fez voltar aos livros paroquiais em busca dos registros de batismo dos filhos do casal. Localizei os assentos de oito filhos (Tabela 1).

5 Cf. VANSINA, Jan. Oral tradition as history. Oxford: James Currey, 1985, p. 196.

6 Arquivo da Cúria Metropolitana de Salvador (ACMS), Freguesia da Conceição da Praia (Freg. CP), Batismos 1814-1824, fl. 159; Casamentos 1843-1864, fl. 51v. 
Tabela 1.

Filhos de Júlia Soares de Sá e Francisco Nazareth de Etra

\begin{tabular}{|c|c|c|c|c|c|c|}
\hline \multicolumn{7}{|c|}{ Registros paroquiais } \\
\hline $\begin{array}{c}\text { Nome } \\
\text { (tradição oral) }\end{array}$ & Nome & Batismo & Nascimento & Mãe & Pai & Observação \\
\hline Herculano & $\begin{array}{l}\text { Herculano - crioulo, } \\
\text { escravo, filho natural }\end{array}$ & $\begin{array}{c}3 / 3 \\
1839\end{array}$ & $\begin{array}{c}28 / 11 \\
1838\end{array}$ & $\begin{array}{c}\text { Júlia - africana, escrava de } \\
\text { Antônio Soares de Sá }\end{array}$ & $\mathrm{n} / \mathrm{c}$ & \\
\hline Maria Pulquéria & $\begin{array}{l}\text { Maria - crioula, livre, } \\
\quad \text { filha natural }\end{array}$ & $\begin{array}{l}29 / 6 \\
1841\end{array}$ & $\begin{array}{l}\text { Jan } \\
1841\end{array}$ & Júlia Soares - africana liberta & $\mathrm{n} / \mathrm{c}$ & \\
\hline $\mathbf{n} / \mathbf{c}$ & $\begin{array}{l}\text { Maria - crioula, livre, } \\
\quad \text { filha natural }\end{array}$ & $\begin{array}{l}11 / 6 \\
1846\end{array}$ & $\begin{array}{c}6 / 7 \\
1843\end{array}$ & Júlia Soares - africana liberta & $\mathrm{n} / \mathrm{c}$ & \\
\hline Francisco & $\begin{array}{c}\text { Francisco-Crioulo, livre, } \\
\text { filho natural }\end{array}$ & $\begin{array}{l}11 / 6 \\
1846\end{array}$ & $\begin{array}{l}24 / 3 \\
1846\end{array}$ & Júlia Soares - africana liberta & $\mathrm{n} / \mathrm{c}$ & $\begin{array}{l}\text { Em documentos posteri- } \\
\text { ores, Francisco Cassiano }\end{array}$ \\
\hline $\begin{array}{c}\text { José } \\
\text { Januário }\end{array}$ & $\begin{array}{l}\text { José - crioulo, livre, } \\
\text { filho natural }\end{array}$ & $\begin{array}{l}27 / 6 \\
1849\end{array}$ & $\begin{array}{l}18 / 3 \\
1849\end{array}$ & Júlia Soares - africana livre (sic) & $\mathrm{n} / \mathrm{c}$ & Falecido em 25/10/1849 \\
\hline Inês & $\begin{array}{l}\text { Anna - crioula, livre, } \\
\text { filha natural }\end{array}$ & $\begin{array}{l}31 / 8 \\
1851\end{array}$ & $\begin{array}{c}8 / 2 \\
1851\end{array}$ & Júlia Soares - africana liberta & $\mathrm{n} / \mathrm{c}$ & $\begin{array}{l}\text { Aparentemente falecida } \\
\text { antes de } 1867\end{array}$ \\
\hline Damiana & $\begin{array}{l}\text { Damiana - crioula, livre, } \\
\text { filha legítima }\end{array}$ & $\begin{array}{c}4 / 6 \\
1854\end{array}$ & $\begin{array}{l}\text { Fev } \\
1854\end{array}$ & $\begin{array}{c}\text { Júlia Soares de Sá } \\
\text { africana liberta }\end{array}$ & $\begin{array}{l}\text { Francisco Nazareth } \\
\text { de Etra - africano liberto }\end{array}$ & $\begin{array}{l}\text { Avó materna de Mãe } \\
\text { Menininha }\end{array}$ \\
\hline Jacinto Marciano & $\begin{array}{l}\text { Jacintho-Crioulo, livre, } \\
\text { filho legítimo }\end{array}$ & $\begin{array}{c}29 / 11 \\
1858\end{array}$ & $\begin{array}{l}30 / 7 \\
1858\end{array}$ & $\begin{array}{c}\text { Júlia Ignez de Etra } \\
\text { africana liberta }\end{array}$ & $\begin{array}{l}\text { Francisco Nazareth } \\
\text { de Etra - africano liberto }\end{array}$ & \\
\hline Cassiano & & & & $\mathrm{a} / \mathrm{c}$ & & Ver Francisco, acima \\
\hline
\end{tabular}

Fontes: Entrevista com Carmen Oliveira, Salvador, 3/9/2013; NÓBREGA, Cida; ECHEVERRÍA, Regina. Mãe Menininha: uma biografia. Salvador: Corrupio, 2006, p. 12-13; Arquivo Metropolitano da Cúria de Salvador, Freg. da Conceição da Praia, Batismos 1834-1844, fls. 87, 131; Batismos 1844-1864, fls. 20v, 65, 98, 144v, 196v, 201. 
O casamento católico tardio de Francisco Nazareth de Etra e Júlia Soares de Sá, em 1853, depois de mais de duas décadas juntos, explica a ausência de indicação de paternidade nos registros dos filhos nascidos antes dessa data. Quando se tratava de um filho "natural" - nascido de pais solteiros -, apenas a mãe era identificada, mesmo quando havia união estável.7 Observamos que, em quase todos os casos, os prenomes coincidem com a tradição oral, porém nos registros de batismo não constam segundos prenomes. Isso era corriqueiro na época. Nomes adicionais eram anotados apenas quando se tratava de famílias influentes. Portanto, a filha batizada em 1841 como Maria decerto é a mesma que, como adulta, seria conhecida como Maria Pulquéria da Conceição, visto que esta, de acordo com a memória oral, nasceu em 1840. Já quanto aos dois filhos lembrados como Francisco e Cassiano, a documentação revelou que eram uma só pessoa: o menino que em 1846 recebeu o nome de Francisco aparece em documentos posteriores como Francisco Cassiano. ${ }^{8}$

O registro de batismo do primogênito, Herculano, nascido quando Júlia ainda era escrava, fornece o nome do senhor, Antônio Soares de Sá. Assim, torna-se claro que os sobrenomes usados por Júlia depois de liberta vieram do patrono, de acordo com o costume da época. Porém, com o passar dos anos, ela se afastava desse legado do cativeiro. Em 1858, no batismo do filho caçula, ela trocou o sobrenome do senhor para o do marido, identificandose como "Júlia Ignez de Etra". Entretanto, introduziu-se outro vestígio do antigo laço senhorial: o prenome Ignez era da esposa de Antônio Soares de Sá.?

\footnotetext{
7 Sobre famílias africanas na Bahia nesse período, cf. MATTOSO, Kátia de Queiroz. Bahia, século XIX: uma província no Império. Rio de Janeiro: Nova Fronteira, 1992, p. 134-135; 144-145; REIS, Isabel Cristina Ferreira dos. A família negra no tempo da escravidão: Bahia, 1850-1888. Tese de doutorado, História, Universidade Estadual de Campinas, Campinas, São Paulo, 2007; para discussões de famílias de libertos, cf. OLIVEIRA, Maria Inês Cortes de. O liberto: seu e os outros. São Paulo: Corrupio, 1988, p. 58-73; REIS, João José. Domingos Sodré, um sacerdote africano: escravidão, liberdade e candomblé na Bahia do século XIX. São Paulo: Companhia das Letras, 2008, p. 108; 241; 244; CASTILLO, Lisa Earl \& PARÉS, Luis Nicolau. Marcelina da Silva e seu mundo: novos dados para uma historiografia do candomblé ketu. Afro-Ásia, Salvador, n. 36, 2007, p. 116-117; CASTILLO, Lisa Earl. O terreiro do Alaketu e seus fundadores: história e genealogia familiar, 1807-1867. Afro-Ásia, Salvador, n. 43, 2011, p. 219-222.

8 ACMS, Freg. de Santana, Batismos 1865-1871, fl. 25v; Maria Júlia Ignez Soares d'Etra ao Presidente da Província, Arquivo Público da Bahia (APB), Militares, Guerra de Paraguai, 1865-1869, Maço 3670, 20 nov. 1867.

9 ACMS, Freg. CP, Batismos 1844-1864, fls. 87, 144v, 196v; Batismos 1824-1834, fl. 286. Falecida poucos anos depois do batismo de Júlia, a esposa de Antonio Soares de Sá se chamava Josefa Ignez Carolina Fernandes. A tradição oral diz que Júlia teve uma filha de nome Inês, mas não há memórias nítidas e ela não consta nos livros de batismo.
} 
Em 1867, num requerimento redigido a rogo de "Maria Júlia Ignez Soares de Etra", vejamos de novo o prenome da patrona, com o sobrenome do patrono já de volta. Observamos ainda, pela primeira vez, o uso de ambos os prenomes lembrados pela tradição oral, contudo somente no final do século começam a aparecer documentos com o nome completo recordado hoje. Nos registros de impostos municipais sobre logradouros (IPTU), a partir de 1893, "Maria Júlia da Conceição" e "Maria Pulcheria da Conceição" constam como inquilinas da loja e do primeiro andar do sobrado $n^{\circ} 12$, na Rua da Assembleia, Freguesia da Sé - o mesmo endereço lembrado na tradição oral como o local de nascimento de Mãe Menininha. ${ }^{10}$ A adoção do sobrenome "da Conceição" por mãe e filha sinalizava sua devoção à Nossa Senhora da Conceição, o mais difundido culto mariano no Brasil, especialmente expressiva entre a população feminina negra-africana. ${ }^{11}$

\section{Antes da chegada ao Brasil: na terra dos egbás}

Num artigo publicado em 1942, o sociólogo E. Franklin Frazier afirmou, com base em depoimentos de Mãe Menininha, que a fundadora do Gantois era de nação jeje-mahi e seu marido era egbá-araké. Porém, de acordo com a memória oral, Francisco Nazareth que era jeje-mahi. Como vimos acima, a nação jeje é confirmada pelos registros paroquiais, deixando em aberto apenas a questão do subgrupo mahi. Na memória oral, quem era egbá-araké - ou alaké, como é grafado em iorubá - era Maria Júlia. Essa informação já foi registrada em 1917, poucos anos depois da morte da fundadora, por Manuel Querino, que fazia parte da "família de santo" da casa, ocupando o posto de ogã. No texto de Querino, aparece o retrato da fundadora, com a

\footnotetext{
${ }^{10}$ Maria Júlia Ignez Soares d'Etra ao Presidente da Província, op. cit.; Arquivo Municipal de Salvador (AMS), Registros de IPTU, Freg. da Sé: 1893, vol. 1, fl. 32; 1896, vol. 1., fl. 32. Sobre o endereço, cf. NÓBREGA, Cida; ECHEVERRÍA, Regina. Mãe Menininha do Gantois: uma biografia. Salvador: Corrupio, 2006, p. 11.

${ }^{11}$ Sobre a devoção à N. Sra. da Conceição, cf. SOUZA, Juliana Beatriz de Almeida. Virgem imperial: Nossa Senhora e império marítimo português. Luso-Brazilian Review, Ann Arbor, vol. 45, n. 1, 2008, p. 30-52; SOUSA JUNIOR, Vilson Caetano de. Orixás, santos e festas. Salvador: Uneb, 2003, p. 92-94. Nomes devocionais, como Do Bonfim, De Jesus, Dos Santos e Da Conceição eram usados por alguns libertos desde a liberdade ou até antes dela, mas havia outros que os assumiam anos depois. Foi o caso da africana liberta Amelia Felicia Chapelin, que no início da década de 1860 mudou de nome, tornando-se Felicia Maria da Conceição Silva. AMS, Escrituras de compra e venda de escravos, Freg. CP, 1863-1864, fl. 6.
} 
legenda: "A antiga mãe do Gantois, tipo egbá" (Figura 1). ${ }^{12}$

Segundo a tradição oral do Gantois, o nome iorubá de Maria Júlia era Omoniké. Contudo, o antropólogo Vivaldo da Costa Lima associou esse nome com a sucessora de Marcelina da Silva na liderança da Casa Branca, também chamada Maria Júlia, mas de sobrenome Figueiredo. Adotado também por Verger, essa informação acabou se tornando senso comum na literatura etnográfica, mas a versão do Gantois é respaldada por evidências rituais de ambos os terreiros. No Gantois, Omoniké é um dos primeiros antepassados femininos a ser chamado quando, nos ritos fúnebres, são recitados os nomes dos ancestrais da casa, o que ressalta seu papel fundamental nos primeiros tempos do terreiro. No mesmo ritual na Casa Branca, entretanto, o nome Omoniké não consta. ${ }^{13}$
Figura 1 -

"Antiga mãe do Gantois, tipo egbá". Fonte: QUERINO (1917).

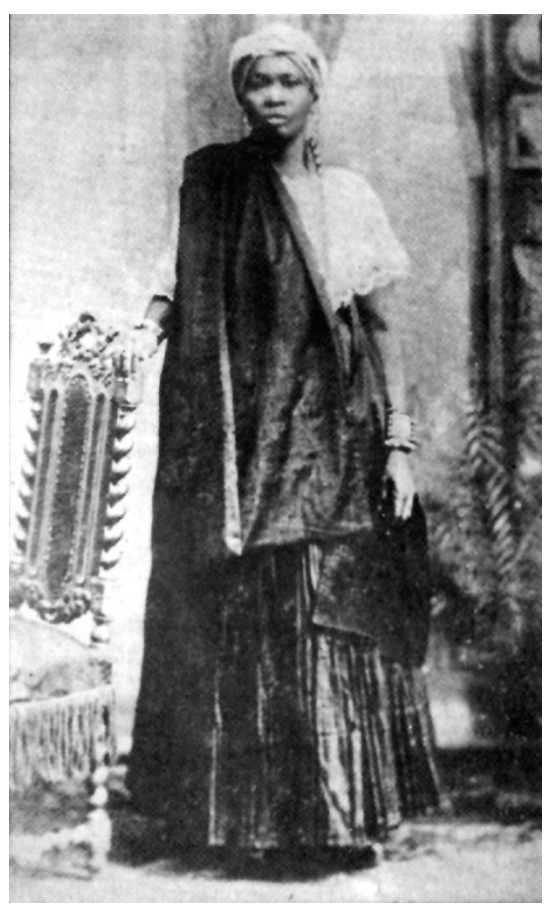

A memória da nação específica de Omoniké ajuda a desvendar a sequência de eventos que levaram à sua escravização. Os egbás são um grupo

\footnotetext{
${ }^{12}$ Cf. FRAZIER, Edward Franklin. The Negro family in Bahia, Brazil. American Sociological Review, New York, vol. 7, n. 4, 1942, p. 473-474; entrevista com Carmen Oliveira, 1/9/2013; "Depoimento de Mãe Menininha", no LP Mãe Menininha do Gantois. São Paulo: Phonodisc, 1974, faixa 1. No candomblé, o posto de ogã é conferido a homens que não recebem o orixá, mas auxiliam o funcionamento do terreiro de outras formas, exercendo funções rituais e/ou formando representando o terreiro perante a sociedade externa. Cf. LIMA, Vivaldo da Costa. A família de santo nos candomblés jeje-nagôs da Bahia. Salvador: Corrupio, 2003, p. 89-94.

${ }^{13}$ Cf. Entrevista com Carmen Oliveira, 3/9/2013; entrevista com Areelson Antonio Conceição Chagas, Elemaxó da Casa Branca, 1/4/2017; LIMA, Vivaldo da Costa. A família de santo nos candomblés jeje-nagôs da Bahia. Salvador: Corrupio, 2003, p. 145; VERGER, Pierre. Orixás. Salvador: Corrupio, 2003, p. 29; SANTOS, Juana Elbein dos. Os nagô e a morte: padê, àsèsè e o culto egun na Bahia. Belo Horizonte: Vozes, 2002, p. 182-199. O nome Omoniké denota uma criança que recebe atenção especial dos pais: Willys de Andrade Santos, Kwara State University, Ilorin, Nigéria, comunicação pessoal.
} 
iorubá cujo reino é localizado no centro-sul da Iorubalândia, dentro da zona da floresta, à margem leste do rio Ogun. Eram divididos em três subgrupos, dos quais um era os egbá-alakés, que ocupavam a região no extremo sul do reino. Como diversos outros povos iorubás, os egbás foram subordinados durante muito tempo ao poder político do reino de Oyó. Contudo, por volta de 1780, se aproveitaram de disputas internas na metrópole e se rebelarem, conseguindo, assim, autonomia. ${ }^{14}$

A estabilidade política dos egbás, porém, durou pouco. Com o enfraquecimento progressivo de Oyó nas primeiras décadas do século XIX, guerras civis se espalharam na Iorubalândia. Por volta de 1817, começou a guerra de Owu, uma cidade a nordeste do território egbá. A guerra começou quando os owus atacaram Ilê-Ifé, em retaliação pela falta de providências dessa cidade diante de quadrilhas que andavam sequestrando pessoas para vender como escravos e depois se escondiam no território de Ilê-Ifé. Nessa guerra, que durou anos, entrou também outro grupo iorubá, os ijebus. Atravessadores no tráfico de escravos, os ijebus tinham interesse em proteger a oferta de cativos. Os egbás procuravam manter neutralidade, mas o conflito invadiu seu território. Owu foi destruída e, até 1829, quase todo o reino egbá foi engolido. Os milhares de prisioneiros se tornaram escravos: alguns aproveitados para escravidão local, outros encaminhados ao litoral para venda no tráfico atlântico, principalmente por Onim (como a cidade de Lagos era então conhecida), estimulando, assim, o crescimento dessa cidade como porto negreiro. De Onim, os cativos foram embarcados para o Brasil ou para Cuba. ${ }^{15}$

A vez da fundadora do Gantois, porém, ainda estava por chegar. ${ }^{16}$ A julgar pela idade de 40 anos atribuída a ela no registro do casamento, ela

\footnotetext{
${ }^{14}$ Cf. BIOBAKU, Saburi Oladeni. The Egba and their neighbours, 1842-1872. Oxford: Clarendon, 1957, p. 7; 9-13. Sobre os eventos em Oyó, cf. LAW, Robin. The Oyo Empire, c.1600-c.1836: a West African imperialism in the era of the Atlantic slave trade. Oxford: Clarendon Press, 1977; JOHNSON, Samuel. The history of the Yorubas from the earliest times to the beginning of the British Protectorate. Lagos: C.S.S. Bookshops, 1969 [1921], p. 197-202; 212-22; REIS, João José. Rebelião escrava no Brasil: a história do levante dos malês em 1835. 2. ed. São Paulo: Companhia das Letras, 2003, p. 158-174.

${ }^{15}$ Cf. BIOBAKU, Saburi. The Egba and their neighbours, 1842-1872. Oxford: Clarendon, 1957, p. 13; MANN, Kristin. Slavery and the birth of African city: Lagos, 1760-1900. Bloomington: Indiana University Press, 2007, p. 42-44; MABOGUNJE, Akin; OMER-COOPER, John. Owu in Yoruba history. Ibadan: Ibadan University Press, 1971, p. 57-66; 76-79; OJO, Olatunji. Heepa (Hail) Ori a: the Orisa factor in the birth of Yoruba identity. Journal of Religion in Africa, Ann Arbor, vol. 39, 2009, p. 36.

${ }^{16}$ Para uma análise da influência da guerra de Owu no tráfico de escravos ao Brasil, cf. MANN, Kristin. The illegal slave trade and one Yoruba man's transatlantic passages from slavery to freedom. In: MISEVICH, Philip \& MANN, Kristin (org.). The rise and demise of slavery and the slave trade in the Atlantic world. Rochester: University of Rochester Press, 2016, p. 220-246.
} 
nasceu por volta de 1813. Quando a guerra começou, ela era criança ainda. A tradição oral conta que Omoniké veio ao Brasil muito jovem, mas por outro lado se afirma também que ela era "de Abeokuta". ${ }^{17}$ Essa cidade, entretanto, foi fundada apenas em 1830, por refugiados da guerra de Owu. Provavelmente, Omoniké nasceu no território dos egbá-alaké e, depois, a família foi deslocada pela guerra e se refugiou em Abeokuta. No caso, a centralidade da cidade na tradição oral seria um reflexo de sua importância como lugar de abrigo num momento de crise e carência.

Situada às margens do rio Ogun, rodeada por terras férteis, a nova cidade estava ao lado de uma enorme rocha de granito. Por isso, ganhou o nome de Abeokuta, que significa literalmente "debaixo da rocha". Os moradores se organizaram em quatro bairros, de acordo com suas etnias. ${ }^{18}$ Um deles era de refugiados owus, enquanto os outros correspondiam aos três subgrupos egbás. De acordo com a tradição oral do Gantois, Omoniké era "natural do povoado de Akê, em Abeokuta", do que se pode inferir que a família se estabeleceu no distrito dos egbá-alaké, seus parentes de nação. A cidade foi murada de acordo com o costume iorubá, mas mesmo assim era alvo constante de bandidos, que "atacavam as roças e sequestravam em pleno dia qualquer um que se atrevia a botar o pé fora dos muros". Os raptores faziam parte de quadrilhas que traficavam cativos para venda a atravessadores do comércio negreiro. Os alvos preferidos dos bandidos eram indivíduos e pequenos grupos que saíam do perímetro urbano para buscar água ou cuidar dos plantios nas roças. Entre os numerosos incidentes dessa natureza de que se tem notícia nos primeiros anos de Abeokuta, destaca-se um grande ataque por ijebus, em 1832, e outro, em 1834, em que os agressores foram os egbados, outro grupo iorubá vizinho. ${ }^{19}$

Na tradição oral do Gantois, uma lembrança fragmentada sobre o dia em que Omoniké foi escravizada evoca o clima de medo que pairava sobre Abeokuta nesse período. Conta-se que naquele dia, o pai, preocupado com o

${ }_{17}$ ACMS, Freg. CP, Casamentos 1843-1864, fl. 51v; entrevista com Carmen Oliveira, 3/9/2013.

${ }^{18}$ Cf. BIOBAKU, Saburi Oladeni. The Egba and their neighbours, 1842-1872. Oxford: Clarendon, 1957, p. 17-18. Esse modelo de organização urbana seria repetido em outras cidades iorubás que receberam migrantes no século XIX, como Lagos e Ibadan. Sobre o caso de Lagos, cf. OTERO, Solimar. Afro-Cuban diasporas in the Atlantic world. Rochester: University of Rochester Press, 2013, p. 65-70.

${ }^{19}$ Cf. NÓBREGA, Cida E ECHEVERRÍA, Regina. Mãe Menininha do Gantois: uma biografia. Salvador: Corrupio, 2006, p. 11; BIOBAKU, Saburi Oladeni. The Egba and their neighbours, 1842-1872. Oxford: Clarendon, 1957, p. 16-22; JOHNSON, Samuel. The history of the Yorubas from the earliest times to the beginning of the British Protectorate. Lagos: C.S.S. Bookshop, 1969 [1921], p. 248-251. 
perigo de sequestro, deu à filha uma semente para colocar na boca, antes de sair de casa com ela, para lhe tornar invisível aos inimigos. A mesma providência, tomada pelo pai, serviu bem a ele quando apareceram os bandidos. A filha, porém, não conseguiu se esquivar. Foi raptada e vendida a traficantes. ${ }^{20}$

\section{Escrava na Bahia}

No outro lado do oceano, na Cidade da Bahia, como Salvador era então conhecida, Omoniké foi comprada por Antônio Soares de Sá, um branco que morava na Freguesia da Conceição da Praia. Localizada em uma estreita faixa de terra espremida entre a Baía de Todos-os-Santos e uma ribanceira, a freguesia era o centro comercial da cidade, abrigando o porto e atividades associadas, bem como lojas, mercados e sedes de empresas. ${ }^{21}$ Era uma das freguesias mais populosas da cidade, com grande e crescente número de escravos. Entre 1821 e 1832, o cônego da imponente igreja matriz contabilizou um total de três mil batismos. Quase dois terços eram cativos, a grande maioria africana. ${ }^{22}$

Na freguesia também moravam muitos libertos, engajados no comércio ou em serviços relacionados às atividades náuticas. ${ }^{23}$ As nações africanas ali representadas eram diversas, mas havia um crescente número de iorubá-falantes, a maioria escravizada em consequência das guerras em suas terras natais ou da insegurança social e política generalizada que as guerras provocaram. ${ }^{24}$ Contudo, não foi na Freguesia da Conceição que Omoniké foi batizada. Em 29 de novembro de 1835, Antônio Soares de Sá subiu a ribanceira com sua

\footnotetext{
${ }^{20}$ Entrevista com Carmen Oliveira, 3/9/2013. Os iorubás tinham muitos tipos de amuletos protetores, entre os quais os aferi, que tornavam o portador invisível. Cf. PAYNE, John Augustus Otonba. Table of principal events in Yoruba history. Lagos: Andrew M. Thomas, 1893, p. 27.

${ }^{21}$ Cf. SAMPAIO, Consuelo Novaes. 50 anos de urbanização: Salvador da Bahia no século XIX. Salvador: Odebrecht, 2005, p. 32-37; SOARES, Carlos Eugênio Líbano. Sacramento ao pé do mar: batismo de africanos na freguesia da Conceição da Praia, 1700-1751. Revista de Estudos Afro-Americanos, Rio de Janeiro, vol. 1, n. 1, 2011, p. 65-88.

22 ACMS, Freg. CP, Batismos 1834-1844, fl. 3v. Segundo o cônego, mulheres constituíram 46\% dos africanos batizados nesse período.

${ }^{23}$ Cf. SOARES, Carlos Eugênio Líbano. Sacramento ao pé do mar: batismo de africanos na freguesia da Conceição da Praia, 1700-1751. Revista de Estudos Afro-Americanos, Rio de Janeiro, vol. 1, n. 1, 2011, p. 69

${ }^{24}$ Sobre a população africana nesta época, cf. OLIVEIRA, Maria Inês Cortes de. Viver e morrer no meio dos seus: nações e comunidades africanas na Bahia do século XIX. Revista USP, São Paulo, n. 28, 1995-1996, p. 175-193; REIS, João José. Rebelião escrava no Brasil: a história do levante dos malês em 1835. 2. ed. São Paulo: Companhia das Letras, 1991, p. 307-309.
} 
nova escrava para a Igreja Matriz da Freguesia da Sé, na Cidade Alta. Ao passar pelo sacramento, Omoniké se tornou conhecida legalmente como Júlia. ${ }^{25}$

A rigor, escravos africanos tinham que ser batizados dentro de um ano depois de chegar ao Brasil, uma regra que nem sempre era cumprida. Mas quando Júlia foi batizada havia pressão redobrada sobre os senhores para serem mais atentos ao catequismo da escravaria. Em janeiro daquele ano, havia explodido em Salvador a rebelião conhecida como a Revolta dos Malês, liderada por nagôs islamizados. Espantado pelo caráter religioso da insurreição, o governo provincial criou legislação que obrigava os senhores a batizar cativos africanos dentro de seis meses, com uma multa de \$50.000 réis para os infratores. Parece provável, portanto, que no dia de seu batismo, Júlia tinha cerca de seis meses na Bahia. No caso, ela teria chegado no meio da caça às bruxas que seguiu o levante malogrado. Nesse contexto, certamente o processo de choque cultural sempre vivenciado pelos africanos recém-chegados foi mais intenso, diante das novas medidas repressivas e do sentimento antiafricano que tomava conta da população branca e mestiça. ${ }^{26}$

O senhor de Júlia era sócio da empresa Ramos Soares e Costa. Com um armazém no térreo de um sobrado nas proximidades do porto, a firma fornecia produtos e serviços para embarcações. No primeiro andar, seu escritório organizava fretes e passagens marítimas. Para os anos de 1830, a documentação evidencia apenas envolvimento em viagens de cabotagem, mas ao longo da década anterior a empresa fazia carregações de cativos dos portos da África meridional. ${ }^{27}$ Tinha navio negreiro próprio, o brigue Nossa Senhora da Glória. Em uma de viagens, enquanto o tumbeiro voltava de Moçambique, uma epidemia de varíola matou mais de 10\% dos quase 300 cativos a bordo. ${ }^{28}$ Depois de 1831, quando entrou em vigência uma lei que visava acabar

\footnotetext{
${ }^{25}$ ACMS, Freg. da Sé, Batismos 1829-1861, fl. 138v. Foi padrinho o branco Miguel da Cruz, morador da Sé. Ao que parece, era amigo do senhor de Júlia.

${ }^{26}$ REIS, João José. Rebelião escrava no Brasil: a história do levante dos malês em 1835. 2. ed. São Paulo: Companhia das Letras, 1991, p. 479-508; BRITO, Luciana da Cruz. Temores da África: segurança, legislação e população africana na Bahia oitocentista. Salvador: UFBA, 2016.

${ }^{27}$ Cf. Correio Mercantil, 3 maio 1839, p. 4; Correio Mercantil, 28 out. 1839, p. 3; Correio Mercantil, 7 nov. 1839, p. 4; Correio Mercantil, 24 out. 1839, p. 4; Correio Mercantil, 29 abr. 1840, p. 4; Ramos, Soares $e$ Costa vs. Maria de Azevedo Almeida (1830), APB, Libelo Civel 15/540/08, fls. 3v, 4v, 10, 25; Livro de Notas (LN) 268, fls. 184-185.

${ }^{28}$ House of Commons Parliamentary Papers (HCPP), Irish University Press, vol. 12 (1829-31), Brazil, Consular, Bahia, p. 89, n. 52, Weiss a Aberdeen, encl. 1, Importation of Slaves in the Port of Bahia, jul./dez. 1829; Banco de dados Slave Voyages, <www.slavevoyages.org>, viagem n. 1136, acessado em 17 set. 2016; Libelo Civel de Ramos, Soares e Costa, op. cit., fls. 3v, 10 e passim. Depois
} 
com o tráfico negreiro com a África, não há mais indícios do envolvimento da firma nesse comércio. Contudo, os sócios ainda mantinham negócios com notórios traficantes. É muito provável que, como no caso de outras empresas desse tipo, por debaixo dos panos Ramos Soares e Costa ainda estavam emaranhados no tráfico clandestino, o que continuou em pleno vapor até 1851. ${ }^{29}$

A casa de Antônio Soares de Sá, a poucas quadras da empresa, ficava na Rua Direita de Santa Bárbara. Ele morava com a mulher e três filhas, bem como provavelmente com a maioria de seus escravos. Encontrei registros de 16 cativos no total. Júlia foi uma das últimas a ser adquirida. Quando ela chegou, os senhores tinham dez outros africanos (sete mulheres e três homens), além de um menino crioulo, filho de uma das africanas. Os homens, todos nagôs, realizavam serviços relacionados à empresa do senhor, como calafetagem. As mulheres vinham de várias nações e Júlia foi uma de três descritas como nagôs. ${ }^{30}$

Um documento de 1846 descreve Júlia, já liberta, como quitandeira. Ela certamente começou esse tipo de trabalho no cativeiro, percorrendo as ruas com tabuleiro na cabeça, ou sentada em algum ponto fixo, rodeada por balaios, talvez na porta da casa dos senhores. A casa, aliás, era muito bem situada para isso: ficava ao lado do mercado de Santa Bárbara, o maior da cidade. Lá, como nas ruas, as mulheres negras predominavam na venda de alimentos, recriando, assim, a importância feminina nas feiras africanas. Na Iorubalândia, em particular, de acordo com a divisão tradicional do trabalho, a agricultura era um âmbito masculino, mas a venda da safra e de

do desembarque do brigue no final de 1829, mais de dez outros cativos morreram da mesma doença: ACMS, Freg. do Pilar, Óbitos 1824-34, fls, 37v-39v.

${ }^{29}$ Um dos clientes da empresa era André Pinto da Silveira, que começou sua carreira como capitão de navios negreiros e, posteriormente, tornou-se proprietário de embarcações, ainda atuando como agente na Bahia de Francisco Félix de Souza, o Chachá, que controlava o tráfico em Uidá. Cf. VERGER, Pierre. Fluxo e refluxo do tráfico de escravos entre o Golfo do Benin e a Bahia de Todos os Santos, séculos XVII-XIX. 4. ed. Salvador: Corrupio, 2002, p. 489; LAW, Robin. A carreira de Francisco Félix de Souza na África Ocidental (1800-1849). Topoi, Rio de Janeiro, vol. 2, n. 2, 2001, p. 22. Sobre a relação de Silveira com a empresa: APB, LN 268, fls. 184-185.

${ }^{30}$ ACMS, Freg. CP, Batismos 1815-1824, fl. 286; Batismos 1824-1834, fl. 337; ACMS, Freg. CP, Batismos 1834-1844, 16, 19, 20 dez. 1827 (números das folhas ilegíveis), fl. 117; Freg. da Sé, Batismos 1829-1861, fls. 27v, 59, 66; APB, LN 276, fls. 28-31; LN 240A, fl. 140; LN 262, fls. 112v-113; LN 276, fls. 28-31, Índice de alforrias, 1841-43. A Rua Direita de Santa Bárbara é atualmente conhecida como a Rua Pinto Martins, via que faz ligação com o início da Ladeira da Montanha. 
outros produtos, comestíveis ou não, era responsabilidade das mulheres, o que lhes trazia oportunidades de se tornarem negociantes. ${ }^{31}$

Nesse âmbito, Júlia decerto tinha contato constante com gente de diversas nações africanas, inclusive a sua. Naquela altura, entre a população cativa, os nagôs já constituíam um grupo majoritário. Com as guerras na Iorubalândia, chegavam cada vez mais oyos, owus, ijebus e egbas. Mas entre os africanos libertos - residentes na cidade há mais tempo -, o perfil demográfico refletia períodos anteriores do tráfico negreiro, quando predominavam os angolas, haussás e jejes, este último um termo guarda-chuva, aplicado a várias etnias do tronco linguístico gbe das atuais Repúblicas do Benim e do Togo. Os jejes estavam espalhados pela cidade, mas a Freguesia da Conceição da Praia reunia um grande número deles. Desde meados do século XVIII, a freguesia abrigava uma importante confraria daquela nação, a Irmandade de Bom Jesus das Necessidades e da Redenção. ${ }^{32}$

Como já foi dito, a tradição oral sustenta que Francisco Nazareth d'Etra era da nação jeje-mahi. Um dos povos do tronco linguístico gbe, a partir dos anos 1740, os mahis sofriam ataques contínuos do Daomé, que buscava cativos para suprir as demandas do comércio negreiro. Na Bahia, na segunda metade do século XVIII, os cativos "maquins" passaram a constituir um significativo subgrupo da nação jeje, que, por sua vez, era um subgrupo da nação mina, um termo guarda-chuva que surgiu através do tráfico de escravos, para se referir a diversas etnias do Golfo do Benim, como nagôs, haussás e fulanis. ${ }^{33}$ A tradição oral não recorda do nome mahi de Francisco Nazareth, nem dos detalhes de sua escravização.

\footnotetext{
${ }^{31}$ Subdelegado Ignacio Bernardino dos Santos ao chefe da Polícia, Arrolamento de Africanos residentes na Freguesia da Conceição da Praia. 31 jan. 1846, APB, Polícia, Maço 6472; FARIAS, Juliana Barreto. Mercados minas: africanos ocidentais na Praça do Mercado do Rio de Janeiro (1830-1890). Rio de Janeiro: Prefeitura do Rio de Janeiro, 2015; Cf. GRAHAM, Richard. Alimentar a cidade: das vendedoras de rua à reforma liberal (Salvador, 1780-1860). São Paulo: Companhia das Letras, 2013, p. 65-90; FADIPE, Nathaniel Akinremi. The sociology of the Yoruba. Ibadan: Ibadan University Press, 1970, p. 147-157. Sobre o mercado de Santa Bárbara, cf. SAMPAIO, Consuelo Novaes. 50 anos de urbanização: Salvador da Bahia no século XIX. Salvador: Odebrecht, 2005, p. 32-37.

${ }^{32}$ Cf. PARÉS, Luís Nicolau. A formação do candomblé: história e ritual da nação jeje na Bahia. Campinas: Unicamp, 2006, p. 30-39; 72-81; PARÉS, Luís Nicolau. Milicianos, barbeiros e traficantes numa irmandade católica de africanos minas e jejes (Bahia, 1770-1830). Tempo, Niterói, vol. 20, 2014, p. 1-32.

${ }_{33}$ Cf. PARES, Luis Nicolau. A formação do candomblé: história e ritual da nação jeje na Bahia. Campinas: Unicamp, 2006, p. 38-42; SOARES, Mariza de Carvalho. O império de Santo Elesbão na cidade do Rio de Janeiro, no século XVIII. Topoi, Rio de Janeiro, 2002, p. 59-83; SILVA JUNIOR, Carlos da. Slave trade, ethnicity and cultural exchanges between Bahia and the Bight of Benin, 1721-1817. Tese de doutorado, História, Hull, Reino Unido, 2017.
} 
Os registros paroquiais, porém, mostram que "Francisco jeje" foi batizado na Conceição da Praia em 12 de maio de 1799, aos dez anos de idade. Seu senhor, o jeje forro José Antônio d'Etra, era um próspero barbeiro que morava na paróquia há muitos anos. Com a morte do senhor, em 1828, Francisco Nazareth ficou liberto, mas permaneceu na mesma vizinhança, nos arredores do mercado de Santa Bárbara. Assim, foi provavelmente na porta da casa do senhor que Júlia conheceu o futuro marido. O primeiro filho do casal, Herculano, nasceu em 28 de novembro de 1838 e foi batizado três meses depois, em 3 de março de 1839. No registro paroquial, consta que o menino era escravo de Flora Amélia Evarista Soares, filha de Antônio Soares de Sá. O padrinho foi o crioulo forro Manoel José d'Etra, antigo companheiro de cativeiro de Francisco Nazareth e, ao mesmo tempo, filho do finado patrono. ${ }^{34}$

O compadre Manoel era letrado e no ano seguinte, quando Júlia comprou sua liberdade, no dia 25 de setembro de 1840, já grávida de Pulquéria, foi ele quem assinou a carta de alforria como testemunha. ${ }^{35}$ Ela tinha ficado pouco tempo no cativeiro: não completara cinco anos desde seu batismo e tinha menos de 30 anos de idade. Francisco Nazareth ainda não se firmara economicamente e é provável que parte dos \$550.000 réis pagos pela carta viessem do padrinho de Herculano. Um abastado homem de negócios, Manoel frequentemente emprestava dinheiro a juros, inclusive a parentes de amigos para a compra da alforria. ${ }^{36}$ Se ele contribuiu para a liberdade da comadre, certamente ela e o marido se tornaram seus devedores. Mas, para o casal, foi um investimento com vistas ao futuro: quatro meses depois, Pulquéria nascera de ventre livre.

\footnotetext{
${ }^{34}$ AMS, Livro de oficinas, 1790-1813, fls. 6, 70, 78v, 93 e passim; ACMS, Freg. CP, Batismos 17861800, fl. 321; Batismos 1826-34, fl. 337; Testamento de José Antonio d'Etra, APB, Livro de Testamentos (LT) 16, fls. 100-104v.

${ }^{35}$ APB, LN 269, fl. 48v. Agradeço a Urano Andrade pela localização desse documento importante.

${ }^{36}$ Cf. REIS, João José. Domingos Sodré, um sacerdote africano: escravidão, liberdade e candomblé na Bahia do século XIX. São Paulo: Companhia das Letras, 2008, p. 232.
} 


\section{O cativeiro de Francisco Nazareth: relações de poder na comunidade negra-africana}

O patrono de Francisco Nazareth, José Antônio d'Etra, foi senhor de cerca de cinquenta cativos ao longo de sua vida, um número bastante grande para o âmbito urbano e extraordinário para um liberto. Ele fazia parte de uma pequena, mas importante classe de africanos bem-sucedidos, cujo papel estratégico na articulação de redes de sociabilidade negra no Brasil escravista que começou a ser documentada nas últimas décadas. ${ }^{37}$

José Antônio era casado com uma jeje liberta, mas não teve filhos com ela. Porém, como tantos outros senhores, ele tinha relações sexuais com algumas de suas escravas também. Uma delas, Antônia Jeje, forra por ele em 1802 com a condição de serví-lo até sua morte, foi a mãe de Manoel José d'Etra. Batizado como escravo em 1806, sem identificação do pai no registro, o filho Manoel permaneceu no cativeiro por toda a infância. Quando José Antônio escreveu seu testamento em 1828, viúvo, adoentado e sem filhos legítimos, instituiu Manoel como herdeiro universal, mas ainda assim não o declarou como filho. Já que o pai era casado com outra mulher quando Manoel nasceu, este era legalmente um bastardo e, portanto, barrado de ser herdeiro. ${ }^{38}$ A ocultação da relação carnal foi a saída que o pai encontrou para instituir Manoel como herdeiro.

\footnotetext{
${ }^{37}$ Cf. SOARES, Mariza de Carvalho. Devotos da cor: identidade étnica, religiosidade e escravidão no Rio de Janeiro, século XVIII. Rio de Janeiro: Civilização Brasileira, 2000; FARIAS, Sheila de Castro. Sinhás pretas, "damas mercadoras": as pretas minas nas cidades do Rio de Janeiro e de São João del Rey (1700-1850). Tese de livre docência, História do Brasil, Universidade Federal Fluminense, Niterói, Rio de Janeiro, 2004; FRANK, Zephyr. Dutra's world: wealth and family in nineteenth-century Rio de Janeiro. Albuquerque: University of New Mexico Press, 2004; REIS, João José. Domingos Sodré, um sacerdote africano: escravidão, liberdade e candomblé na Bahia do século XIX. São Paulo: Companhia das Letras, 2008; REIS, João José. De escravo a rico liberto: a trajetória do africano Manoel Joaquim Ricardo na Bahia oitocentista. Revista de História da USP, São Paulo, n. 174, 2016, p. 15-68; PARÉS, Luis Nicolau. A formação do candomblé: história e ritual da nação jeje na Bahia. Campinas: Unicamp, 2006. PARÉS, Luis Nicolau. Milicianos, barbeiros e traficantes numa irmandade católica de africanos minas e jejes (Bahia, 1770-1830). Tempo, Niterói, vol. 20, 2014, p. 1-32; PARÉS, Luis Nicolau \& CASTILLO, Lisa Earl. José Pedro Autran e o retorno de Xangô. Religião e Sociedade, Rio de Janeiro, vol. 35, n. 1, 2015, p. 13-43; CASTILLO, Lisa Earl. O terreiro do Alaketu e seus fundadores: história e genealogia familiar, 1807-1867. Afro-Ásia, Salvador, n. 43, 2011, p. 213-259.

${ }^{8}$ APB, LN 210, fl. 181v; AMCS, Freg. CP, Batismos 1800-06, fl. 162v; Testamento de José Antonio d'Etra, op. cit., fls. 100-104; AMS, Registros de Licenças, 1815-1820, fl. 275; Cf. MATTOSO, Kátia de Queiroz. Bahia, século XIX: uma província no Império. Rio de Janeiro: Nova Fronteira, 1992, p. 136-137.
} 
Em 1809, ao completar dez anos no cativeiro, Francisco Nazareth recebeu uma carta de alforria, sob a mesma condição da mãe de Manoel. No seu testamento, José Antônio reafirmou a promessa feita ao escravo que já lhe servia por três décadas: entre os mais de quinze cativos forrados pelo testador, o nome de Francisco Nazareth estava em primeiro lugar. De acordo com o estudo pioneiro da historiadora Maria Inês Cortes de Oliveira, sobre testamentos de africanos libertos na Bahia, entre 1790 e 1850, cerca de 200 declararam possuir cativos. Apenas três testadores - entre eles José Antônio d'Etra - tinham mais de 20 escravos. Ele era, evidentemente, um dos africanos mais ricos da cidade. Mas tinha sido mais rico ainda. No testamento, ele reclamava das privações da guerra de independência, que acabaram com suas reservas de dinheiro e metais preciosos. ${ }^{39}$

Francisco Nazareth era barbeiro como o senhor e muitos outros escravos da casa exerciam o mesmo ofício, inclusive Manoel (Tabela 2), provavelmente treinados pelo próprio senhor. No Brasil Colônia e ainda durante o Império, a maioria dos barbeiros era negra ou africana e ser músico era um dos atributos do ofício. Barbeiros também realizavam diversas práticas de cura, como sangrar, aplicar ventosas e sanguessugas. Os mais habilidosos extraíam dentes e tratavam fraturas de osso. Por esse motivo, eram requisitados para trabalhar em navios que faziam viagens de grande porte, inclusive navios negreiros, o que criava oportunidades para voltar ao continente de origem. Pelo menos três libertos da casa d'Etra foram à África nessa condição. ${ }^{40}$

\footnotetext{
${ }^{39}$ OLIVEIRA, Maria Inês Cortes de. O liberto: seu mundo e os outros. São Paulo: Corrupio, 1988, p. 40-41; Testamento de José Antonio d'Etra, op. cit., fl. 101. Sobre José Antonio d'Etra, cf. PARÉS, Luis Nicolau. Milicianos, barbeiros e traficantes numa irmandade católica de africanos minas e jejes (Bahia, 1770-1830). Tempo, Niterói, vol. 20, 2014, p. 20-23.

${ }^{40}$ RUSSELL-WOOD, Anthony John. Slavery and freedom in colonial Brazil. Oxford: Oneworld, 2002, p 56-57; PIMENTA, Tânia Salgado. Barbeiros-sangradores e curandeiros no Brasil (1808-1828). História, Ciências, Saúde - Manguinhos, Rio de Janeiro, vol. 5, n. 2, 1998, p. 349-372; RODRIGUES, Jaime. De costa a costa: escravos, marinheiros e intermediários do tráfico negreiro de Angola ao Rio de Janeiro (1780-1860). São Paulo: Companhia das Letras, 2005, p. 271-282; SOARES, Mariza de Carvalho. African barbers in Brazilian slave ports. In: CAÑIZARES-ESGUERRA, Jorge et al. (org.). The black urban Atlantic in the age of the slave trade. Filadélfia: University of Pennsylvania Press, 2013, p. 207-230; PARÉS, Luis Nicolau. Milicianos, barbeiros e traficantes numa irmandade católica de africanos minas e jejes (Bahia, 1770-1830). Tempo, Niterói, vol. 20, 2014, p. 1-32.
} 
Tabela 2 - Barbeiros da casa d'Etra

\begin{tabular}{|c|c|c|c|c|c|c|}
\hline Nome & Nação & Senhor & Batismo & Alforria & Óbito & Outros dados \\
\hline José Antonio & jeje & $\begin{array}{c}\text { Francisco José } \\
\text { d'Etra }\end{array}$ & $?$ & $<1782$ & 1828 & $\begin{array}{l}\text { Irmão do Rosário (Portas } \\
\text { do Carmo e Conceição da } \\
\text { Praia); S. Benedito (Convento } \\
\text { de S. Francisco e Conceição } \\
\text { da Praia), B. Jesus da Re- } \\
\text { denção. }\end{array}$ \\
\hline $\begin{array}{l}\text { Francisco } \\
\text { Nazareth }\end{array}$ & jeje & $\begin{array}{l}\text { José Antonio } \\
\text { d'Etra }\end{array}$ & 1799 & 1828 & 1859 & \\
\hline Maximiano & mina & $\begin{array}{l}\text { José Antonio } \\
\text { d'Etra }\end{array}$ & c.1800 & - & 1811 & $\begin{array}{l}\text { Irmão do Rosário da Con- } \\
\text { ceição da Praia }\end{array}$ \\
\hline Manoel & crioulo & $\begin{array}{l}\text { Filho de José } \\
\text { Antonio d'Etra, } \\
\text { nasceu escravo } \\
\text { do pai }\end{array}$ & 1806 & $\begin{array}{l}\text { c.1826- } \\
1827\end{array}$ & 1856 & $\begin{array}{l}\text { Irmão do Rosário (Portas } \\
\text { do Carmo e Conceição da } \\
\text { Praia), B. Jesus da Redenção; } \\
\text { Sociedade Protetora dos } \\
\text { Desvalidos. }\end{array}$ \\
\hline Athanazio & nagô & $\begin{array}{c}\text { José Antonio } \\
\text { d'Etra }\end{array}$ & 1824 & 1828 & $?$ & \\
\hline Olavo & crioulo & $\begin{array}{c}\text { Filho de Manoel } \\
\text { José d'Etra, nasceu } \\
\text { livre }\end{array}$ & 1834 & $\begin{array}{l}\text { Nasceu } \\
\text { livre }\end{array}$ & 1859 & $\begin{array}{l}\text { Irmão do Rosário das Portas } \\
\text { do Carmo }\end{array}$ \\
\hline Ciriaco & nagô & $\begin{array}{l}\text { 1) José Antonio } \\
\text { d'Etra } \\
\text { 2) Manoel José } \\
\text { d'Etra }\end{array}$ & 1825 & 1838 & $?$ & \\
\hline Barnabé & nagô & $\begin{array}{l}\text { 1) José Antonio } \\
\text { d'Etra } \\
\text { 2) Manoel José } \\
\text { d'Etra }\end{array}$ & 1828 & 1856 & 1873 & \\
\hline Domingos & $\begin{array}{l}\text { S. } \\
\text { Thomé }\end{array}$ & $\begin{array}{l}\text { Manoel José } \\
\text { d'Etra }\end{array}$ & 1839 & 1851 & 1880 & $\begin{array}{l}\text { Irmão do Rosário (Portas do } \\
\text { Carmo e Conceição da Praia) }\end{array}$ \\
\hline Adão Ciriaco & nagô & Ciriaco d'Etra & $<1848$ & $<1852$ & $?$ & \\
\hline Henrique & nagô & $\begin{array}{l}\text { 1) Francisco } \\
\text { Nazareth d'Etra } \\
\text { 2) Manoel José } \\
\text { d'Etra } \\
\text { 3) Olavo José } \\
\text { d'Etra }\end{array}$ & $1831 ?$ & 1859 & $?$ & \\
\hline Floripes & jeje & $\begin{array}{l}\text { 1) Manoel José } \\
\text { d'Etra } \\
\text { 2) Olavo José } \\
\text { d'Etra }\end{array}$ & 1831 & 1859 & 1877 & \\
\hline $\begin{array}{l}\text { Leocadio } \\
\text { Francisco }\end{array}$ & crioulo & $?$ & c.1837 & $?$ & 1865 & \\
\hline Venâncio & crioulo & $\begin{array}{c}\text { José Antonio } \\
\text { d'Etra }\end{array}$ & 1824 & 1828 & $?$ & \\
\hline
\end{tabular}

Fontes: Almanach Civil, Político e Comercial da Cidade da Bahia (1845), Salvador, Secretaria de Cultura e Turismo, 1998, p. 246247; Almanak Mercantil e Administrativo da Bahia, 1854-1863; Marieta Alves, "Música de barbeiros"; Reis, Domingos Sodré, p. 402; Correio Mercantil, 1840-1849, Gazeta da Bahia, 1880; ACMS, Freg. CP, Batismos 1786-1864; Freg. CP, Óbitos, 1810-1828, fl. 11v; Freg. de S. Pedro, óbitos 1855-1896, fl. 316; Testamento de José Antonio de Etra; op. cit.; AMS, Livro de Oficinas, 17901813; Termos dos exames de cirurgia, sangria, partos e dentistas, 1825-1828; Arquivo da Ordem Terceira do Rosário do Pelourinho (ARP), Termos de Posse da diretoria, sec. XIX; Livro de Irmãos, s/d; Irmandade do Rosário dos Pretos da Conceição da Praia, Receitas e Despesas, 1848-1877; APB, Livro de Notas 325, fl. 38v, Registros de Passaportes, Maço 5896. 
A residência do senhor, na Rua das Grades de Ferro nos entornos do mercado de Santa Bárbara, abrigava sua oficina de barbearia e também sediava uma banda de música liderada por ele, em que os escravos barbeiros tocavam. Desde pelo menos 1782, a banda tocava em festas populares católicas. A trajetória continuada desse conjunto musical depois da morte do fundador revela os persistentes vínculos financeiros e provavelmente afetivos também entre a família senhorial e os libertos da casa. Com o falecimento de José Antônio, seu filho Manoel prosseguiu com as atividades musicais, no mesmo endereço.

Em 1845, um almanaque local caracterizava o grupo como o melhor da cidade, opinião ecoada, mais de meio século depois, pelo estudioso Manuel Querino. ${ }^{41}$ Com a morte de Manoel José d'Etra, em 1856, a banda passou para seu filho, Olavo. Este morreu três anos depois, sem descendentes, legando a banda para um certo Leocadio Francisco d'Etra que, por volta de 1862, passou o grupo para ainda outro liberto da casa, Floripes d'Etra. Este, de nação jeje, tinha sido batizado escravo por Manoel em 1831, e depois herdado por Olavo, que ao morrer o forrou por verba testamental. ${ }^{42}$

Em 1877, quando Floripes faleceu, seus únicos bens eram instrumentos musicais de sopro, percussão e cordas. No inventário post-mortem, também constam diversos recibos de pagamentos feitos à banda por participações em festas católicas, na capital e nas ilhas da Baía de Todos os Santos. Há indícios de que Floripes era amigo dos filhos de Júlia e Francisco Nazareth, e é possível que Herculano - que era barbeiro como o pai - tocasse na banda. Ainda que ele não fizesse, o certo é que bandas de barbeiros figuravam em vários eventos organizados pela família. Ao que parece, a música funcionava como um espaço de emprego e de sociabilidade para os membros da casa d'Etra, perpassando várias gerações. Esse tipo de situação se reproduzia em outras partes do Brasil, como sugere a pesquisa de Silvana Jeha sobre outra bem-sucedida banda de barbeiros no Rio de Janeiro. ${ }^{43}$

\footnotetext{
${ }^{41}$ AMS, Livro de oficinas, 1790-1813, fls. 6, 93, 110v; Almanach Civil, p. 247; cf. ALVES, Marieta. Música de barbeiros. Revista Brasileira de Folclore, Rio de Janeiro, vol. 7, n. 17, 1967, p. 10; 12-13; QUERINO, Manuel. Costumes africanos no Brasil. Rio de Janeiro: Civilização Brasileira, 1938, p. 319-320.

${ }^{42}$ ACMS, Freg. CP, Batismos 1824-1834, fls. 229v, 230; Freg. da Sé, Batismos 1829-1840, fl. 73v; Inventário de Olavo José d'Etra (1859), APB, 05/1969/24, fl. 4; Almanak Administrativo e Mercantil da Bahia, Salvador, Camillo de Lellis Mason e Cia: (1860), p. 63; (1862), p. 332.

${ }^{43}$ Inventário de Floripes d'Etra (1877), APB, 03/1246/1715/04, fls. 12-13, 16; O Monitor, 25 jul. 1878, p. 2; O Alabama, 20 jan. 1866, p. 2-3; cf. JEHA, Silvana. Ganhar a vida: uma história do barbeiro africano Antônio José Dutra e sua família. Rio de Janeiro, século XIX. Revista de História, Rio de Janeiro, n. 176, 2017, p. 22.
} 
Mãe Carmen se lembra de ouvir sua mãe falar do envolvimento do bisavô e dos tios com a música. Em relação a Francisco Nazareth, Manuel Querino foi mais longe, afirmando que tinha banda própria, também sustentando que era "capitão de milícias". Na família, não consta memória alguma disso e a cronologia da vida de Francisco Nazareth nega a possibilidade de ele ter sido miliciano. As milícias negras, os chamados "Terços de Henriques", eram um fenômeno do Brasil Colônia. Constituídas por libertos e livres, ficaram extintas com a independência, quando Francisco Nazareth ainda era escravo. Embora alguns cativos, inclusive africanos, tivessem lutado na guerra de independência, não encontrei registros que sugiram que fosse o caso de Francisco Nazareth. Ademais, a Guarda Nacional, criada em 1831, admitia apenas cidadãos brasileiros, apesar de não discriminar pela cor da pele. ${ }^{44}$ Por ser africano, Francisco Nazareth era excluído.

Na verdade, tudo indica que a trajetória militar apontada por Querino foi do senhor de Francisco Nazareth. Em 1793, José Antônio d'Etra recebeu uma patente de capitão de assaltos e entradas, conferida pelo governador da capitania da Bahia. ${ }^{45} \mathrm{O}$ documento cita uma provisão de 26 de novembro de 1714, que autorizava "a criação dos postos de capitães-mores-das-entradas dos mocambos" na região do Recôncavo da Bahia. Esse tipo de patente, distinta daquelas das outras milícias negras, surgiu na Bahia no século XVIII para incentivar a apreensão de escravos fugidos. Tinha a mesma função que o capitão do mato e o mesmo sistema de remuneração: apenas os prêmios pagos pelos senhores dos fugitivos capturados. ${ }^{46}$

No catolicismo popular, Santo Antônio era considerado o padroeiro dos caçadores de escravos fugidos. Esse era apenas um aspecto dos poderes mais

\footnotetext{
${ }^{44}$ Entrevista com Carmen Oliveira, 1/9/2013; cf. QUERINO, Manuel. Costumes africanos no Brasil. Rio de Janeiro: Civilização Brasileira, 1938, p. 45; 319-320; REIS, João José. Divining slavery and freedom: the story of Domingos Sodré, an African priest in nineteenth-century Brazil. New York: Cambridge University Press, 2015, p. 56-57; KRAAY, Hendrik. Identidade nacional na política. Bahia, 1790-1840: o caso dos Henriques. In: JANCSÓ, István (org.). Brasil: formação do estado e da nação. São Paulo: Hucitec, 2003, p. 521-546.

${ }^{45}$ Carta Patente de José Antonio de Etre [sic], 6 set. 1793, Arquivo Histórico Ultramarino (AHU), Brasil, Bahia, Cx. 81, doc. 15.750; cf. PARÉS, Luis Nicolau. Milicianos, barbeiros e traficantes numa irmandade católica de africanos minas e jejes (Bahia, 1770-1830). Tempo, Niterói, vol. 20, 2014, p. 1-32; COTTA, Francis Albert. Negros e mestiços nas milícias da América portuguesa. Belo Horizonte: Crisálida, 2010.

${ }^{46}$ AHU, Registro de Ordens Régias, Cod. 247, fls. 1-1v; cf. LARA, Silvia Hunold. Do singular ao plural - Palmares, capitães do mato e o governo dos escravos. In: REIS, João Jose \& GOMES, Flávio dos Santos. Liberdade por um fio: história dos quilombos no Brasil. São Paulo: Companhia das Letras, 1996, p. 81-109.
} 
amplos desse santo sobre objetos perdidos ou almejados. Especialmente na Bahia, Santo Antônio se tornou protetor de militares, o que seguramente motivou sua associação, no sincretismo afro-baiano, com Ogum, orixá guerreiro-caçador e protetor de ferreiros e de todas as outras profissões que dependem de objetos de metal. Isso incluía, evidentemente, os barbeiros, que além de depender da navalha para o exercício de seu trabalho, ainda ofereciam outros serviços envolvendo ferramentas de metal, como a amolação de facas. Significativamente, Francisco Nazareth é lembrado como "filho" (devoto) de Ogum. A evidente afinidade com seu ofício sugere que fosse iniciado no âmbito da casa senhorial, talvez junto com outros escravos da casa. ${ }^{47}$

José Antônio d'Etra fazia parte de uma extensa rede social constituída principalmente por barbeiros africanos que, como ele, eram milicianos e membros de confrarias negras, alguns com cargos importantes. Nesse meio social, a irmandade de Bom Jesus das Necessidades e da Redenção, fundada por jejes na Igreja do Corpo Santo, era um espaço fundamental de agregação. Em sua análise dessa irmandade, Luis Nicolau Parés apresenta evidências que, na última quartela do século XVIII e início do XIX, muitos dos irmãos eram barbeiros com patentes militares, alguns envolvidos no tráfico de escravos. ${ }^{48}$ José Antônio ainda fazia parte de duas outras confrarias: a de São Benedito e do Rosário dos Pretos. Seu filho, Manoel, tinha cargos nas diretorias das irmandades do Rosário das Portas do Carmo e da Conceição da Praia e foi uma figura de destaque na Sociedade Protetora dos Desvalidos. ${ }^{49}$ Se pertencer a múltiplas irmandades simbolizava status social, ser eleito à diretoria trazia ainda mais prestígio. Ao subir nas hierarquias dos espaços

\footnotetext{
${ }^{47}$ Cf. MOTT, Luiz. Santo Antonio, o divino capitão-do-mato. In: REIS, João José E GOMES, Flávio dos Santos. Liberdade por um fio: história dos quilombos no Brasil. São Paulo: Companhia das Letras, 1996, p. 130-134; VAINFAS, Ronaldo. Santo Antônio na América portuguesa: religiosidade e política. Revista USP, São Paulo, n. 57, 2003, p. 32-33; QUERINO, Manuel. Costumes africanos no Brasil. Rio de Janeiro: Civilização Brasileira, 1938, p. 48; VERGER, Pierre. Notas sobre o culto aos orixás e voduns. São Paulo: USP, 1999, p. 157; SOARES, Mariza de Carvalho. African barbers in Brazilian slave ports. In: CAÑIZARES-ESGUERRA, Jorge et al. (org.). The black urban Atlantic in the age of the slave trade. Filadélfia: University of Pennsylvania Press, 2013.

${ }^{48}$ Cf. PARÉS, Luis Nicolau. Milicianos, barbeiros e traficantes numa irmandade católica de africanos minas e jejes (Bahia, 1770-1830). Tempo, Niterói, vol. 20, 2014, p. 1-32.

${ }^{49}$ ACMS, Freg. CP, Óbitos 1810-1828, fl. 314v; ARP, Despesas da Irmandade do Rosário da Conceição da Praia, fl. 25v, Termos de posse da diretoria, 1825-1922, fls. 9, 15, 17, 23; 25; BRAGA, Julio Santana. Sociedade Protetora dos Desvalidos: uma irmandade de cor. Salvador: Ianamá, 1987, p. 72.
} 
mais requisitados da comunidade negro-africana, José Antônio e sua família acumulavam importante capital simbólico. ${ }^{50}$

A posição social da família senhorial oferecia certas vantagens para os escravos da casa d'Etra, comparado com cativos de senhores brancos ou até de africanos menos bem-sucedidos. Ainda que de forma desigual, os escravos da casa passavam a integrar a extensa rede social dos senhores, desde o batismo formando laços - fossem solidários, clientelistas, ou uma mistura dos dois - com africanos libertos que frequentemente eram de sua própria nação e que tinham alcançado certo nível de conforto, prestígio e até de poder. A trajetória do próprio Francisco Nazareth d'Etra deixa isso muito claro. Teve como padrinho um amigo de confiança do senhor, o jeje liberto Antônio Narciso Martins da Costa, que nos anos a seguir apadrinhara outros escravos da casa. Capitão de assaltos e entradas, membro de irmandades e proprietário de imóveis e escravos, Antônio Narciso era também mestre de navios negreiros, uma ocupação extraordinária para um africano liberto. ${ }^{51}$ Nas viagens à Costa da Mina, a habilidade de Antônio Narciso com as línguas gbe certamente facilitava as negociações com os atravessadores negreiros. Muito provavelmente, foi essa mesma habilidade linguística que influenciou a escolha, no final de 1812, de um navio sob seu comando, a sumaca Pistola, para a viagem de volta de uma embaixada do Rei do Daomé. $\mathrm{O}$ ano seguinte, quando a sumaca retornou à Bahia, ainda com Antonio Narciso no leme, trazia 366 escravos, panos da costa e ouro. ${ }^{52}$

\footnotetext{
${ }^{50}$ Cf. REGINALDO, Lucilene. Os rosários dos angolas: irmandades de africanos e crioulos na Bahia setecentista. São Paulo: Alameda, 2011, p. 97-164; OLIVEIRA, Maria Inês Cortes de. O liberto: seu mundo e os outros. São Paulo: Corrupio, p. 79-87; SOARES, Mariza de Carvalho. Devotos da cor: identidade étnica, religiosidade e escravidão no Rio de Janeiro, século XVIII. Rio de Janeiro: Civilização Brasileira, p. 165-196.

${ }^{51}$ Cf. ACMS, Freg. CP, Batismos 1786-1800, fl. 321; Batismos 1806-1809, fl. 26v; Batismos 1814-1824, fl. 159; Batismos 1815-1824, fl. 224v; Freg. do Pilar, Batismos 1790-1801, fl. 140v; Carta Patente de Antonio Narciso. AHU, Brasil, Bahia, Cx. 81, doc. 23.010-23.011. Sobre a atuação de Antonio Narciso como capitão negreiro, cf. REIS, João José. Escravos donos de escravos na Bahia oitocentista. Texto apresentado no seminário do grupo de pesquisa Escravidão e Invenção da Liberdade, Universidade Federal da Bahia, maio de 2013. Além de apadrinhar vários outros cativos de José Antonio, Antonio Narciso era também testamenteiro da esposa. Testamento de Mariana da Silva Pereira, APB, LT 3, fl. 32. Agradeço a Luis Nicolau Parés por compartilhar esse documento.

52 Relação de embarcações para sair, Idade d'Ouro, 13 nov. 1812, p. 4; Embarcações que entraram neste Porto, Idade d'Ouro, 17 ago. 1813, p. 4; cf. VERGER, Pierre. Fluxo e refluxo do tráfico de escravos entre o Golfo do Benin e a Bahia de Todos os Santos, séculos XVII-XIX. 4. ed. Salvador: Corrupio, 2002, p. 302-305; SOARES, Mariza de Carvalho. Trocando galanterias: a diplomacia do comércio de escravos, Brasil-Daomé, 1810-1812. Afro-Ásia, Salvador, n. 49, 2014, p. 229-27; ARAUJO, Ana Lucia. Dahomey, Portugal and Bahia: King Adandozan and the Atlantic slave trade. Slavery E Abolition,
} 
Tudo indica que foi por meio desse padrinho poderoso que Francisco Nazareth, ainda no cativeiro, se tornou dono de um escravo. Entre maio de 1817 e fevereiro de 1819, Antônio Narciso fez três viagens ao porto de Cabinda. Em 20 de maio de 1819, Francisco Nazareth levou para a pia batismal um escravo próprio, de nação cabinda. ${ }^{53}$ Porém, alguns escravos-senhores permaneciam no cativeiro, vivendo com certa autonomia e gozando de outros privilégios concedidos pelo senhor. Esse parece ter sido o caso de Francisco Nazareth, cuja liberdade condicional, concedida dez anos antes do batismo de seu escravo, não trazia a perspectiva de uma saída imediata do cativeiro. No caso, a aquisição do escravo pode ser interpretada como um investimento visando uma vida material melhor, além de destacar seu status diferenciado em relação a outros cativos.

Outro indício de que Francisco Nazareth desfrutava de certos privilégios na escravaria da casa d'Etra é que serviu de padrinho seis vezes, entre 1813 e 1826. O único outro escravo da casa que andava pela cidade apadrinhando era o próprio filho do senhor, que teve cinco afilhados entre 1821 e 1826. Três dos afilhados de Francisco Nazareth eram escravos jejes, enquanto os outros nasceram no Brasil, filhos de mães africanas. Uma dessas comadres era forra e o filho nascera livre, o que chama atenção. Na época, a escolha de padrinhos geralmente seguia uma complexa hierarquia social, fundamentada em cor e condição jurídica, com a aristocracia branca no topo, seguida por comerciantes brancos, depois livres e libertos de cor. Em último lugar, situavam-se os escravos africanos. Já não era muito comum que pais de crioulos livres escolhessem um africano para apadrinhar seus filhos. Optar por um padrinho que estivesse no cativeiro, ainda que tivesse a promessa de liberdade, era raro. ${ }^{54}$

Em 7 de maio de 1828, José Antônio d'Etra morreu. Foi enterrado na igreja matriz da Conceição da Praia depois de uma grande procissão fúnebre que envolveu cinco irmandades e dezesseis padres, bem como certamente

\footnotetext{
Abingdon, vol. 33, n. 1, 2012, p. 1-19; Banco de Dados Slave Voyages, www.slavevoyages.org, viagens n. 47178, 7334, 7396, 9, 48667, 48826, 7356 e 2952.

53 Idade d'Ouro, 23 fev. 1819, p. 5; Banco de Dados Slave Voyages, http://www.slavevoyages.org, viagem nº48826, acessado em 26/7/2015; ACMS, Freg. CP, Batismos 1815-24, fl. 133; Batismos 180609, fl. 26v. Em uma análise minuciosa sobre o fenômeno do "escravo-senhor", o historiador João José Reis mostra que muitas vezes o cativo seria treinado pelo dono com vistas a sua própria alforria, com o intuito de fornecer um substituto para si. REIS, João José. Escravos donos de escravos na Bahia oitocentista. Texto apresentado no seminário do grupo de pesquisa Escravidão e a Invenção da Liberdade, Universidade Federal da Bahia, maio de 2013.

${ }^{54}$ ACMS, Freg. CP, Batismos 1815-24, fls. 158v, 162, 292; Batismos 1824-1834, fls. 39v; MATTOSO, Kátia. Bahia, século XIX: uma provincial no Império. Rio de Janeiro: Nova Fronteira, 1992, p. 175.
} 
as dezenas de membros da casa d'Etra, entre eles Francisco Nazareth. ${ }^{55}$ Assim foi que depois de trinta anos no cativeiro, Francisco Nazareth d'Etra pôde ir ao cartório, em 16 de junho daquele ano, para finalmente registrar a carta de liberdade que guardava desde 1809. Pouco depois, em 7 de julho, faleceu seu padrinho, Antônio Narciso Martins da Costa. A procissão, maior ainda, contava com 22 padres e seu lugar de descanso final foi o mais requisitado da elite africana, o Convento de São Francisco. ${ }^{56}$ Assim, a passagem de Francisco Nazareth da escravidão para a liberdade foi marcada pela perda das duas figuras paternalistas que tinham marcado sua trajetória no Brasil.

\section{O espaço social de Júlia e Francisco Nazareth}

Antônio Soares de Sá morreu em 12 de janeiro de 1843, quando o primogênito de Julia e seu marido tinha quatro anos de idade. Como vimos, o menino, Herculano, era escravo da filha do senhor de Julia, Flora Amélia Evaristo Soares. Depois da morte do pai, ela casou-se com Manoel José de Figueiredo Leite, futuro provedor da irmandade da Santa Casa de Misericórdia da Bahia, reduto exclusivo da elite baiana. ${ }^{57}$ Não consegui apurar quanto tempo Herculano ficou sob o poder da família senhorial, nem a data de sua alforria, mas é provável que tenha sido resgatado ainda menino, porque depois de liberto usava o sobrenome do pai, não da patrona.

Depois da liberdade de Júlia, não há evidências de contatos com outros ex-escravos da família Soares de Sá. Pelo contrário, tudo indica que ela foi absorvida pelo círculo social do marido que, como vimos, envolvia relações clientelistas com libertos de prestígio. A forte influência do mundo de Francisco Nazareth na vida do casal se evidencia claramente na escolha dos

\footnotetext{
55 ACMS, Freg. CP, Óbitos 1810-1828, fl. 314v; Participaram do enterro as irmandades de Bom Jesus da Redenção e das Necessidades; do Rosário e de São Benedito (ambas da Conceição da Praia); do Rosário das Portas do Carmo e de São Benedito (do Convento de São Francisco).

${ }^{56}$ ACMS, Freg. do Pilar, Óbitos 1824-1834, fl. 27. Sobre as irmandades negras que funcionavam no Convento de São Francisco, cf. REGINALDO, Lucilene. Irmandades e devoções de africanos e crioulos na Bahia setecentista: histórias e experiências atlânticas. Stockholm Review of Latin American Studies, Stockholm, n. 4, 2009, p. 29-31.

57 ACMS, Freg. CP, Óbitos 1834-1847, fl. 150; Freg. CP, Casamentos 1843-64, fl. 9v; Freg. S. Pedro, Óbitos 1880-1911, fl. 47v; APB, Liberdade judicial de Ambrosio nagô, APB, LN 276, fls. 28-32. Sobre a Santa Casa da Misericórdia, cf. MATTOSO, Kátia de Queiros. Bahia, século XIX: uma provincial no Império. Rio de Janeiro: Nova Fronteira, 1992, p. 398; RUSSELL-WOOD, Anthony John. Fidalgos and philanthropists: The Santa Casa da Misericórdia da Bahia, 1550-1755. Berkeley: University of California Press, 1968, p. 116-145.
} 
padrinhos dos outros filhos, sobretudo os que nasceram antes do casamento católico em 1853 (Tabela 3). ${ }^{58}$

\section{Tabela 3}

\section{Compadres de Júlia Soares de Sá e Francisco Nazareth de Etra}

\begin{tabular}{|c|c|c|c|c|c|}
\hline & $\begin{array}{l}\text { Filho/data de } \\
\text { batismo }\end{array}$ & Padrinho & Alforria & Morte & $\begin{array}{c}\text { Dados biográficos do } \\
\text { padrinho }\end{array}$ \\
\hline \multirow{5}{*}{ 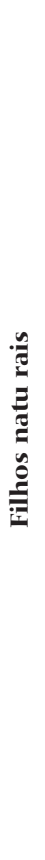 } & $\begin{array}{c}\text { Maria [Pulquéria] } \\
29 / 6 / 1841\end{array}$ & $\begin{array}{l}\text { Marcianno de Almeida } \\
\text { africano }\end{array}$ & c.1827 & $x^{2}$ & $\begin{array}{c}\text { Barbeiro, dono de banda } \\
\text { de música } \\
\text { Irmão do Rosário } \\
\text { (Conceição da Praia e } \\
\text { Portas do Carmo); } \\
\text { Sociedade Protetora } \\
\text { dos Desvalidos. } \\
\text { Barbeiro; dono de banda } \\
\text { de música } \\
\text { Irmão do Rosário } \\
\text { (Portas do Carmo) }\end{array}$ \\
\hline & $\begin{array}{c}\text { Maria } \\
11 / 6 / 1846\end{array}$ & $\begin{array}{l}\text { Adolfo Gonçalves Polieiro } \\
\text { angola }\end{array}$ & $16 / 12 / 1842$ & $3 / 9 / 1864$ & $\begin{array}{l}\text { Dono de oficina de polias } \\
\text { Irmão do Rosário } \\
\text { (Conceição da Praia) }\end{array}$ \\
\hline & $\begin{array}{c}\text { Francisco } \\
\text { Cassiano } \\
11 / 6 / 1846\end{array}$ & $\begin{array}{l}\text { Januário Carneiro } \\
\text { crioulo forro }\end{array}$ & 4/3/1822 & $16 / 3 / 1874$ & $\begin{array}{c}\text { Irmão do Rosário } \\
\text { (Conceição da Praia e } \\
\text { Portas do Carmo); } \\
\text { Amigo de Manoel José } \\
\text { d'Etra }\end{array}$ \\
\hline & $\begin{array}{l}\text { José Narciso } \\
\text { 27/6/1849 }\end{array}$ & $\begin{array}{l}\text { Faustino de Santa Anna } \\
\text { Teixeira - jeje mahi }\end{array}$ & $8 / 12 / 1823$ & $30 / 10 / 1855$ & $\begin{array}{c}\text { Irmão do Rosário } \\
\text { (Conceição da Praia); B. } \\
\text { Jesus da Red.. } \\
\text { Amigo de Manoel José } \\
\text { d'Etra }\end{array}$ \\
\hline & $\begin{array}{l}\text { Anna } \\
\text { 31/8/1851 }\end{array}$ & $\begin{array}{l}\text { Lourenço da Silva Bizarro } \\
\text { cotocori }\end{array}$ & $1836-40$ & $?$ & \\
\hline \multirow{2}{*}{ 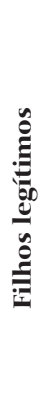 } & $\begin{array}{l}\text { Damiana } \\
4 / 6 / 1854\end{array}$ & $\begin{array}{l}\text { Manoel d'Almeida Lopes } \\
\text { branco } \\
\text { Alexandre José d'Oliveira } \\
\text { branco, "Tocou a coroa de N. Sra." }\end{array}$ & $\mathrm{n} / \mathrm{a}$ & $?$ & $\begin{array}{c}\text { Dono de taverna } \\
\text { Sargento da Guarda } \\
\text { Nacional } \\
\text { Dono de loja de ferragens }\end{array}$ \\
\hline & $\begin{array}{l}\text { Jacintho } \\
\text { Marcianno } \\
\text { 29/11/1858 }\end{array}$ & $\begin{array}{l}\text { Manoel do Carmo Moreira } \\
\text { pardo livre } \\
\text { Olavo José d' Etra } \\
\text { crioulo livre, "Tocou a } \\
\text { coroa de N. Sra." }\end{array}$ & $\mathrm{n} / \mathrm{a}$ & $14 / 6 / 1859$ & $\begin{array}{l}\text { Dono de loja de sapatos } \\
\text { Irmão do Rosário } \\
\text { Filho de Manoel José de } \\
\text { Etra } \\
\text { Barbeiro, dono de banda } \\
\text { Irmão do Rosário }\end{array}$ \\
\hline
\end{tabular}

Fontes: ACMS, Freg. CP, Batismos 1834-1844, fls. 87, 131; Batismos 1844-1864, fls. 20v, 65, 98, 144v,196v; Óbitos 1847-95, fl. 27; Freg. da Sé, Óbitos 1840-62, fl. 54; Freg. de S. Pedro, Óbitos 1855-1859, fl. 316; Óbitos 1880-1911, fl. 28; Almanach Civil, 1845, p. 247; Almanak Administrativo, 1854, p. 334; O Constitucional, 26 jun. 1864, p. 2, "Guarda Nacional"; ARP, Termos de posse da diretoria, 1825-1922, Livro de despesas da Irmandade do Rosário da Conceição da Praia, 1850-1870; Livro de Notas 236., fl. 134.

${ }^{58}$ ACMS, Freg. de São Pedro, Óbitos 1855-59, fl. 316. 
Já vimos que Herculano foi apadrinhado por Manoel José d'Etra. A próxima filha, Maria Pulquéria, teve como padrinho Marciano de Almeida, africano liberto e dono de uma banda de barbeiros na Freguesia da Sé. É possível que, além de tocar na banda da casa d'Etra, Francisco Nazareth também fizesse "bicos" com o conjunto do compadre Marciano. Apesar de não ter bens significativos, Marciano era socialmente bem articulado, talvez pela visibilidade da banda, e tinha mais de vinte afilhados. ${ }^{59}$ Pulquéria foi uma das últimas. Ele morreu em 1843, mas não foi esquecido pelos pais da menina. Mais de quinze anos depois, à procura de um segundo prenome para o filho caçula, Jacinto, colocaram Marciano, em clara homenagem ao falecido músico-barbeiro.

Outro compadre do casal foi o jeje-mahi Faustino de Santa Anna Teixeira. Liberto desde 1823, ele era ativo na diretoria da Irmandade de Bom Jesus desde 1830, com cargos também na irmandade do Rosário da Conceição da Praia. Faustino viajou para a África pelo menos uma vez e era envolvido também na exportação de mercadoria para lá. Nessa atividade, era assessorado por Manoel José d'Etra. O filho apadrinhado por Faustino, batizado em junho de 1849, com o nome de José, morreu em novembro daquele mesmo ano. No registro de óbito, consta um segundo prenome, Narciso, seguramente uma alusão ao finado Antônio Narciso, padrinho de Francisco Nazareth. ${ }^{60}$ Assim, mais uma vez, como no caso de Jacinto Marciano, a escolha do segundo prenome foi uma maneira de manter viva a memória de amigos falecidos.

A tradição oral não se lembra do prenome Narciso; reivindica outro, Januário, que na verdade evidencia a mesma estratégia de nomeação, invocando a memória de outro compadre do casal. Era o crioulo forro Januário Carneiro, padrinho do filho Francisco Cassiano e amigo de longas datas dos compadres Manoel José d'Etra e de Faustino de Santa Anna. Após a morte de Manoel, Januário foi seu testamenteiro e também o substituiu no cargo de tesoureiro da Irmandade do Rosário da Conceição da Praia. ${ }^{61}$ No dia do batismo de Francisco Cassiano, os pais batizaram ainda uma filha, Maria. Não há memória dessa menina, o que sugere que sua vida durou pouco. Seu

\footnotetext{
59 ACMS, Freg. da Sé, Óbitos 1840-62, fl. 54; Almanach Civil, 1845, p. 247.

${ }^{60}$ ACMS, Freg. CP, Batismos, 1844-1864, fls. 20v, 64, 98; APB, LN 231, fl. 113; HCPP, vol. 29 (1846). Class A, n. 26, Her Majesty's Commissioners to the Earl of Aberdeen, Sierra Leone, March 17, 1845, encl. 1, Report of the Case of the Esperança, p. 203.

${ }^{61}$ ACMS, Freg. CP, Casamentos 1843-64, fl. 64v; APB, Testamento de Catharina Maria do Sacramento, 05/2187/2656/14; Partilha amigável de Januário Carneiro (1874), 8/3214/-/22; AOTRP, Livro de Despesas da Irmandade do Rosário da Conceição da Praia, 1850-1870, fl. 25v.
} 
padrinho foi o liberto Adolfo Gonçalves Polieiro, que era bastante envolvido na Irmandade do Rosário da Conceição da Praia.

Adolfo era de nação angola, contudo, apesar da diferença de nação, a amizade com ele não foi passageira, estendendo também a seus familiares. Em 1853, no casamento católico de Francisco Nazareth e Júlia, o genro de Adolfo foi uma das testemunhas. ${ }^{62}$ Passar pelo sacramento do matrimônio era relativamente incomum entre libertos e representava um marco de prestígio. A partir disso, Júlia e Francisco Nazareth passaram a olhar para camadas sociais mais favorecidas na escolha de padrinhos.

Em 1854, quando batizaram a próxima filha, Damiana - futura avó de Mãe Menininha - a cerimônia contava com a participação de dois homens brancos. O padrinho, Manoel de Almeida Lopes, era dono de uma taverna. O comerciante e sargento da Guarda Nacional, Alexandre José de Oliveira, também fez parte do ritual. Ao "tocar a coroa" da madrinha simbólica, Nossa Senhora, ele tornou-se seu representante mortal, efetivamente um segundo padrinho. Novamente, em 1858, duas pessoas atuaram no batismo do filho caçula, Jacinto. Nesse caso, a intermediação com Nossa Senhora foi feita por Olavo, filho de Manoel José d'Etra. O padrinho foi o pardo Manoel do Carmo Moreira, irmão do Rosário das Portas do Carmo e dono de uma loja de sapatos. ${ }^{63}$ Embora essas alianças com as camadas mais favorecidas repercutissem favoravelmente para a família, em termos de prestígio não havia garantias que a relação saísse do papel.

Se a rede de compadrio que Francisco Nazareth e Júlia construíram em torno dos filhos naturais sinaliza a inserção do casal no espaço social da casa d'Etra, a atuação do casal como padrinhos de filhos e de escravos de outrem confirma essa impressão. Já vimos que Francisco Nazareth foi padrinho por seis vezes durante o cativeiro. Depois de sua liberdade, há registro de cinco outros afilhados, batizados entre 1828 e 1851, todos escravos. Mas pouquíssimas novas articulações foram criadas por meio desses novos compadrios. Quase todos os senhores eram velhos conhecidos. Um deles era Manoel José d'Etra; outro era o barbeiro nagô José Bernardino da Costa Farias, que tinha sido escravo de um amigo de José Antônio d'Etra. Irmão do Rosário da Con-

\footnotetext{
${ }^{62}$ ACMS, Freg. CP, Casamentos 1843-1864, fl. 51v; APB, Testamento de Adolfo Gonçalves Polieiro, 5/2190/2659/11.

63 ACMS, Freg. CP, Batismos 1844-1864, fls. 144v, 196v. Sobre a escolha de Nossa Senhora como madrinha simbólica, comum naqueles tempos, cf. MATTOSO, Kátia de Queiroz. Bahia, século XIX: uma província no Império. Rio de Janeiro: Nova Fronteira, 1992, p. 423.
} 
ceição da Praia e escrivão da Irmandade de Bom Jesus das Necessidades, José Bernardino tinha negócios com a África. Como veremos mais adiante, ele provavelmente exerceu um papel importante na aproximação de Júlia com a casa de culto fundada por Iyá Nassô. ${ }^{64}$

Júlia, por sua vez, foi madrinha quatro vezes. ${ }^{65}$ Diferente de outros casais africanos, em que a mulher tendia a participar junto com o marido em batismos, ela e Francisco Nazareth sempre agiam separadamente. No entanto, na maioria das vezes, os padrinhos faziam parte da casa d'Etra. Em março de 1850, quando Júlia foi madrinha de uma africana escravizada e do filho crioulo dela, o padrinho do menino foi o crioulo liberto Venâncio d'Etra, ex-escravo de José Antônio. A próxima vez que Júlia foi à pia batismal, em 3 de outubro de 1852, ela esteve acompanhada pelo crioulo Salustiano d'Etra, cuja mãe, Joana Jeje, era nossa conhecida afilhada de Francisco Nazareth. ${ }^{66}$ Naquele dia, Júlia e Salustiano apadrinharam uma filha de José Bernardino da Costa Farias, o velho conhecido de Francisco Nazareth mencionado no parágrafo acima. A mãe da menina, Anna Ritta nagô, era escrava de certa Maria Clara da Silva, aparentemente africana também. No ano seguinte, Júlia foi madrinha do próximo filho do mesmo casal. O padrinho foi Tito Antônio Monteiro, um barbeiro nagô com tenda ao lado do mercado de Santa Bárbara. Pela proximidade geográfica e pelos laços do ofício, Tito seguramente conhecia o marido da comadre Júlia. ${ }^{67}$

Quatro afilhados não foi um número desprezível para uma mulher africana. Quando se tratava de africanos e crioulos, muitos batismos contavam

\footnotetext{
${ }^{64}$ ACMS, Freg. CP, Batismos 1824-1834, fls. 136, 285v; Batismos 1834-44, fl. 98v; Freg. da Sé, Batismos 1829-61, fl. 289; AOTRP, Livro de despesas da Irmandade do Rosário da Conceição da Praia, 1850-1870, fls. 6, 15, 32v, 26v, 29v, Livro de Termos de Posse de Diretores da Irmandade do Rosário das Portas do Carmo, s/d, fl. 17; Livro de tombamento dos bens das ordens terceiras, irmandades e confrarias de Salvador em 1853. Salvador: Arquivo Público da Bahia, 1948, p. 89.

${ }^{65}$ ACMS, Freg. de Santana, Batismos 1846-65, fl. 58; Freg. CP, Batismos 1844-1864, fls. 130, 137.

${ }^{66}$ ACMS, Freg. CP, Batismos 1815-1824, fl. 292; APB, Testamento de José Antonio d'Etra, op. cit., fls. 100104v. Joana foi escrava de José Antonio, mas com a morte do senhor passou para Manoel José. Salustiano nasceu em 1829, escravo de Manoel José. ACMS, Freg. CP, Batismos, 1824-1834, fl. 195v.

${ }^{67}$ ACMS, Freg. CP, Batismos 1815-1824, fl. 292; Batismos 1844-64, fl. 137; Freg. da Sé, Batismos 1829-1861, fl. 289; APB, Testamento de José Antonio d'Etra, op. cit., fls. 100-104v; LN 308, fl. 32v; AOTRP, Livro de despesas do Rosário da Conceição da Praia, fl. 26v; Almanak Administrativo (1854), p. 310. Sobre a amizade entre os senhores de Francisco Nazareth e José Bernardino, cf. PARÉS, Luis Nicolau. Milicianos, barbeiros e traficantes numa irmandade católica de africanos minas e jejes (Bahia, 1770-1830). Tempo, Niterói, vol. 20, 2014, p. 22-23.
} 
apenas com padrinhos. ${ }^{68}$ Nenhum dos filhos de Júlia e Francisco Nazareth teve madrinha, por exemplo. Mas, comparado a outras ialorixás nagôs do mesmo período, o número de afilhados de Júlia foi relativamente modesto. Em décadas anteriores, a fundadora do Terreiro do Alaketu, Maria do Rosário, liberta por volta de 1810 e falecida em 1850, ganhou dezessete afilhados. Sua contemporânea, Iyá Nassô, fundadora do terreiro hoje conhecido como a Casa Branca, teve oito afilhados entre 1832 e 1835. Sua sucessora, Marcelina da Silva/Obatossi, liberta em 1836 e falecida em 1886, teve nove. Todas ganhadeiras, essas mulheres acumularam posses consideráveis em escravos e imóveis. No caso de Iyá Nassô, seu marido, José Pedro Autran, também exerceu papel definitivo em articulação de redes de compadrio e aquisição de bens. A posse de bens imóveis certamente facilitou a criação de santuários e barracões, enquanto a posse de escravos e a articulação de redes de compadrio serviam para adquirir e mobilizar seguidores. ${ }^{69}$

Em contraste, não há evidência do acúmulo de bens por Júlia ou seu marido. Mesmo comparados com outros ex-escravos de seus próprios senhores, Júlia e Francisco Nazareth não se destacaram materialmente. O calafate nagô, Ignacio Soares, ex-escravo de Antônio Soares de Sá, ao morrer em 1879 era dono de nove escravos e três sobrados no centro da cidade. Outro liberto nagô da família, Duarte Soares, chegou a ter quatro casas térreas no centro da cidade, além de diversos escravos. A trajetória da africana Vicência Antônia Soares, forra no mesmo ano que Júlia, teve apenas duas escravas nagôs, das quais ela se desfez em 1851. Uma foi vendida a terceiros e a outra comprou sua alforria. Os bens de Vicência eram modestos, mas mesmo assim aparentemente superaram os de Júlia. ${ }^{70}$

Em relação à casa d'Etra, além de Manoel José - cuja prosperidade começou com uma herança significativa e por isso representa um caso à parte - os outros libertos não acumularam posses significativas. Ao que parece,

\footnotetext{
${ }^{68}$ MATTOSO, Kátia de Queiroz. Bahia, século XIX: uma província no Império. Rio de Janeiro: Nova Fronteira, 1992, p. 423.

${ }^{69}$ Cf. PARÉS, Luis Nicolau \& CASTILLO, Lisa Earl. José Pedro Autran e o retorno de Xangô. Religião e Sociedade, Rio de Janeiro, vol. 35, n. 1, 2015, p. 39; CASTILLO, Lisa Earl. Bamboxê Obitikô e a expansão do culto aos orixás (século XIX): uma rede religiosa afro-atlântica. Tempo, Niterói, vol. 22, n. 39, 2016, p. 131-132. Para os afilhados de Maria de Rosário, cf. ACMS, Freg. de Santana, Batismos 1811-21, folhas s/n, registros dos dias 6 out. 1816 e 12 fev. 1819; Batismos 1821-1830, fls. 115, 170, 172v, 235v, 242; Batismos 1830-1848, fls.11v, 34v, 92, 145.

${ }^{70}$ Partilha amigável de Ignacio Soares de Sá. APB, 05/2165/2634/38, fls. 9-10v. Inventário de Carlota Miquelina Bastos Soares. APB, 07/3045/12, fls. 10-11v, LN 296, fl. 59v; AMS, Escrituras de compra e venda de escravos, Conceição da Praia, 1848-53, fl. 106v.
} 
o único liberto da casa a se tornar proprietário de imóveis foi Domingos d'Etra, que tinha duas casas térreas na freguesia de Brotas quando faleceu em 1880. ${ }^{71}$ Quanto à posse de escravos, o mais bem-sucedido foi o barbeiro nagô Ciriaco, dono de três escravos de sua própria nação nos últimos anos do tráfico ilegal, provavelmente adquiridos em suas idas à África a trabalho em navios negreiros. ${ }^{72}$ Seis mulheres da casa d'Etra também tiveram pequenas escravarias de um ou no máximo dois cativos adultos. No caso de Francisco Nazareth, lembramos que ele se tornou senhor antes de sair do cativeiro. Depois do batismo, porém, esse escravo, Antônio Cabinda, some dos registros, tendo sido talvez vendido ou falecido. Identifiquei apenas um outro, Henrique, um barbeiro nagô vendido a Manoel José d'Etra em 1844 por $\$ 370.000$ réis, considerado um valor muito baixo - nessa época o preço médio para um escravo adulto do sexo masculino era aproximadamente \$560.000 réis. Tratando-se de um cativo jovem com um ofício lucrativo, era preço de banana. Em 1838, Manoel José tinha cobrado o dobro, $\$ 750.000$ réis, pela liberdade do barbeiro Ciriaco. Em 1840, ele exigiu mais ainda, \$950.000, do também barbeiro, Benedicto. ${ }^{73}$ Já que Francisco Nazareth aparentemente não tinha outros escravos, a decisão de vender Henrique por tão pouco sugere uma necessidade imediata por dinheiro.

Quando Manoel José d'Etra sucedeu o pai na liderança da casa d'Etra, passou a ter uma relação de patrão-cliente com os novos libertos da casa - seus antigos companheiros do cativeiro. Algumas das mulheres permaneciam como agregadas na casa das Grades de Ferro. Os homens residiam numa via perto do Mercado de Santa Bárbara, seu local de trabalho, provavelmente em pequenos quartos compartilhados. Nesse sentido, Francisco Nazareth e sua mulher provavelmente não foram diferentes.

Nos almanaques da época, comerciantes e artesãos costumavam colocar pequenos anúncios com nome e endereço. Barbeiros não eram diferentes. No almanaque de 1845, Francisco Nazareth é o único liberto da casa d'Etra que colocou um anúncio, além do próprio Manoel José d'Etra, que tinha dois: um para a barbearia e outro para a banda. ${ }^{74}$ Na década seguinte,

\footnotetext{
${ }^{71}$ Editais, Gazeta da Bahia, 22 abr. 1880, p. 2.

72 ACMS, Freg. CP, Batismos 1824-1834, fl. 136.

73 Arquivo Municipal de Salvador (AMS), Escrituras de compra e venda de escravos, Freg. CP, 1834-1844, fl. 188; APB, LN 256, fl. 99; LN 269, fl.7v; cf. MATTOSO, Kátia de Queiros et al. Notas sobre as tendências e padrões de preços de alforria na Bahia, 1819-1888. In: REIS, João José (org.). Escravidão e invenção da liberdade: estudos sobre o negro no Brasil. São Paulo: Brasiliense, 1988, p. 66.

${ }^{74}$ Almanach Civil, 1845, p. 246. A edição de 1845 é o único almanaque que sobrevive dos anos 1840.
} 
quatro outros barbeiros d'Etra e o amigo, José Bernardino da Costa Farias, tinham anúncios, mas o próprio Francisco Nazareth não aparece mais. ${ }^{75}$

De acordo com a historiadora Tânia Salgado Pimenta, nos anos 1830 foram introduzidas medidas legislativas que visavam restringir aos médicos e cirurgiões as práticas de cura realizadas por barbeiros, assim reduzindo o campo de atuação destes e, portanto, a rentabilidade do ofício. Contudo, a julgar pelos anúncios nos almanaques na Cidade da Bahia, a decadência do ofício se consolidou apenas no último quartel do século, quando os barbeiros perderam espaço à crescente categoria de cabelereiros e quando anúncios para bandas de música de barbeiros desapareceram. ${ }^{76}$ Mas, nessa altura, Francisco Nazareth já havia morrido há anos. Assim, sua precariedade econômica se devia a outro motivo.

\section{Na encruzilhada da vida}

Na primeira metade dos anos 1850, duas grandes epidemias assolaram o Brasil, apresentando efeitos devastadores nas cidades, nas quais a densidade da população facilitava o contágio. A primeira epidemia, de febre amarela, atacou no verão de 1849-1850, resultando em aproximadamente 1300 fatalidades na cidade de Salvador. Cinco anos depois, estourou outra, de cholera morbus, mais virulenta ainda. Apenas na capital foram nove mil mortos, cerca de 18\% da população urbana. Pessoas envolvidas em comércio e ofícios mecânicos - as ocupações mais frequentes da população negra - foram especialmente atingidas. ${ }^{77}$

O historiador Onildo David aponta para o importante papel, nesse momento de alta demanda para terapias, dos barbeiros que tratavam os doentes

\footnotetext{
75 Almanak Administrativo, 1854, p. 291, 310; Almanak Administrativo, 1855, p. 323, 339; Almanak Administrativo, 1857, p. 352, 370-371; Almanak Administrativo, 1858, p. 347, 364; Almanak Administrativo, 1860, p. 392, 407; Almanak Administrativo, 1862, p. 384, 400; Almanak Administrativo, 1863, p. 384, 400.

76 PIMENTA, Tânia Salgado. Barbeiros-sangradores e curandeiros no Brasil (1808-1828). História, Ciências, Saúde - Manguinhos, Rio de Janeiro, vol. 5, n. 2, 1998, p. 349-375; Almanak Administrativo, 1854, p. 291, 310; Almanak Administrativo, 1855, p. 323, 339; Almanak Administrativo, 1857, p. 352, 370-371; Almanak Administrativo, 1858, p. 347, 364; Almanak Administrativo, 1860, p. 392, 407; Almanak Administrativo, 1862, p. 384, 400; Almanak Administrativo, 1863, p. 384, 400; Almanak Administrativo, Commercial e Industrial, 1872, vol. 4, p. 32; Almanak do Estado da Bahia, 1903, p. 455.

77 Cf. CHALHOUB, Sidney. Cidade febril: cortiços e epidemias na Corte Imperial. São Paulo: Companhia das Letras, 1996; DAVID, Onildo Reis. O inimigo invisível: epidemia na Bahia no século XIX. Salvador: UFBA, 1996, p. 85, 130-131; NASCIMENTO, Anna Amélia Vieira. Dez freguesias de Salvador: aspectos sociais e urbanos do século XIX. Salvador: UFBA, 1986, p. 261-298.
} 
com a sangria. Francisco Nazareth e outros barbeiros de sua rede seguramente prestavam serviços aos coléricos, provavelmente recorrendo também a práticas de cura de origem africana. O contato com os doentes certamente aumentava o risco de infecção. Uma das vítimas foi o compadre Faustino de Santa Anna Teixeira, que morreu no auge da epidemia, em 30 de outubro de 1855. ${ }^{78}$ Ao que parece, entre as pessoas mais próximas a Francisco Nazareth e Júlia, ele foi a única vítima da epidemia. Mas, por azar do destino, a morte perseguiu a família de outras formas pelo resto da década. Pequenos surtos de cólera ainda eclodiam na cidade quando, em 21 de setembro de 1856, Manoel José d'Etra faleceu, aos 50 anos de idade, de "congestão cerebral". Infelizmente, seu testamento não consta nos arquivos da Bahia, o que nos deixa sem saber se alguma parte de seus consideráveis bens chegou a ser legada para seus compadres Francisco Nazareth e Júlia. Com a morte de Manoel, a relação com seu filho, Olavo, tornou-se estratégica, o que contextualiza a aliança de compadrio forjado com ele em 1858, no batismo de Jacinto, caçula de Francisco e Julia. ${ }^{79}$

Poucos meses depois desse batismo, Francisco Nazareth faleceu. Não há rastros da data exata nem da causa, mas nessa altura ele já teria por volta de 70 anos. Em junho do ano seguinte, foi a vez do compadre Olavo, morto com apenas 26 anos de "reumatismo" - provavelmente artrite reumatoide, uma doença autoimune. Poucos dias antes de morrer, Olavo redigiu seu testamento. Sem herdeiros forçados, legou seus bens a um sobrinho e um amigo, mas fez questão de deixar \$200.000 réis para uma certa Maria Clara da Conceição, em gratidão pelos tratamentos contra a doença que o acometia, provavelmente alguma prática terapêutica afro-brasileira. A comadre Júlia não foi mencionada em relação a isso, o que sugere que sua trajetória como ialorixá ainda estivesse numa fase inicial. Contudo, Olavo deixou \$100.000 réis para cada um de seus afilhados, entre eles "Jacinto, filho do finado Francisco Nazareth". ${ }^{80}$

Se a situação financeira da família já era instável durante a vida de Francisco Nazareth, certamente se complicou com a morte dele e desses compadres importantes. Mas os dois filhos mais velhos já tinham idade suficiente para ajudar. Herculano, com 21 anos, era barbeiro como o pai e pro-

\footnotetext{
${ }^{78}$ Cf. CHALHOUB, Sidney. Cidade febril: cortiços e epidemias na Corte Imperial. São Paulo: Companhia das Letras, 1996; DAVID, Onildo Reis. O inimigo invisível: epidemia na Bahia no século XIX. Salvador: UFBA, 1996, p. 85, 130-131; NASCIMENTO, Anna Amélia Vieira. Dez freguesias de Salvador: aspectos sociais e urbanos do século XIX. Salvador: UFBA, 1986, p. 261-298; ACMS, Freg. CP, Óbitos 1847-1895, fl. 92.

${ }^{79}$ ACMS, Freg. S. Pedro, Óbitos 1855-59, fl. 316; APB, Inventário de Olavo Joséd'Etra, 04/1354/1823/87,fl. $1 \mathrm{v}$.

${ }^{80}$ Inventário de Olavo José d'Etra, op.cit.
} 
vavelmente ganhava seu pão na tenda de um dos amigos do pai. ${ }^{81}$ Pulquéria, com 19, provavelmente auxiliava a mãe na quitanda. Nessa conjuntura, Júlia foi com os filhos morar na periferia urbana da Freguesia da Vitória, seguramente na roça em que o terreiro se encontra hoje.

De acordo com a tradição oral, o terreno foi arrendado por Francisco Nazareth em 1849. Não foi encontrada documentação que pudesse confirmar a data, mas o envolvimento do marido de Júlia nos primeiros tempos do terreiro é apoiado por evidências etnográficas: o assentamento mais antigo do terreiro é de Ogum, o orixá de Francisco Nazareth. Contudo, ao longo da década de 1850, os diversos registros paroquiais em que Francisco Nazareth e Júlia aparecem são unânimes em descrevê-los como moradores da Freguesia da Conceição.

No início de 1865, com a declaração de guerra contra o Paraguai, Francisco Cassiano, já com 18 anos, alistou-se como voluntário. O sentimento público a favor da mobilização foi expressivo e não foram poucos os negros libertos e livres que lutaram no conflito. Na Bahia, formaram-se onze companhias negras, os chamados "zuavos". ${ }^{82}$ Muitos dos zuavos eram recém-libertos, mas os dados disponíveis sugerem que os líderes, em muitos casos, nasceram livres, filhos de libertos africanos e crioulos bem-sucedidos. Alguns líderes zuavos eram, inclusive, vinculados a terreiros de candomblé: o alferes Marcellino Gomes do Sacramento, neto dos fundadores do Terreiro do Alaketu, e o também alferes Candido da Fonseca Galvão, o famoso Dom Obá, cujo pai era compadre de Marcelina da Silva, ialorixá da Casa Branca. ${ }^{83}$ Mas muitos outros soldados negros fizeram parte de batalhões que eram racialmente misturados. O próprio Francisco Cassiano integrava o $10^{\circ}$ batalhão de Voluntários da Pátria, com cerca de 400 praças do corpo da polícia.

\footnotetext{
${ }^{81}$ Qualificação de eleitores, Curato da Sé. $O$ Monitor, 25 jul. 1878, p. 2.

${ }^{82}$ Cf. KRAAY, Hendrik. Os companheiros de dom Obá. Afro-Ásia, Salvador, n. 46, p. 121-161; FÉLIX JÚNIOR, Osvaldo Silva. O envio de negros da Bahia para a Guerra do Paraguai. História E Perspectivas, Uberlândia, vol. 24, n. 45, 2011, p. 379-410; SOUZA, Maria Regina Santos de. Impactos da "Guerra do Paraguai" na Província do Ceará (1865-1870). Dissertação de mestrado, História, Universidade Federal do Ceará, Fortaleza, Ceará, 2007, p. 148.

${ }^{83}$ Cf. Desembargador Luis Antonio para a Secretaria do Governo e Relação da força de voluntários que marcharam desta capital, s/d, APB, Militares, Guerra de Paraguai, 1865-1867, Maço 3668; Marcelino Gomes do Sacramento ao Presidente da Província, 5 ago. 1873, APB, Militares, Guerra de Paraguai, 1866-1888, Maço 3675; KRAAY, Hendrik. Os companheiros de dom Obá: os zuavos baianos e outras companhias negras na Guerra do Paraguai. Afro-Ásia, Salvador, n. 46, p. 121-161; CASTILLO, Lisa Earl. O terreiro do Alaketu e seus fundadores: história e genealogia familiar, 1807-1867. Afro-Ásia, Salvador, n. 43, 2011, p. 236-237; 239; 248; 251-252; CASTILLO, Lisa Earl. Bamboxê Obitikô e a expansão do culto aos orixás (século XIX): uma rede religiosa afro-atlântica. Tempo, Niterói, vol. 22, n. 39, 2016, p. 141-144.
} 
Liderado pelo Tenente Coronel Joaquim Maurício Ferreira, Comandante da Polícia e irmão da enfermeira Ana Nery, foi o primeiro batalhão a sair da província, em janeiro de $1865 .^{84}$

Com a ida de Francisco Cassiano para as trincheiras de guerra, as dificuldades financeiras já enfrentadas pela mãe aparentemente se intensificaram. No final de 1867, ela recorreu à caridade pública encaminhando um pedido de auxílio ao Presidente da Província:

\begin{abstract}
Maria Júlia Ignez Soares d'Etra, viúva de Francisco de Nazareth d'Etra, tendo em sua companhia dois filhos menores, de nomes Damiana, com idade de treze anos e Jacintho, com nove, sendo viúva pobre, requer a $\mathrm{V}$. Exa. lhe mande dar uma quantia das quais se acham destinadas para as famílias dos voluntários da Pátria, visto ter a Suplicante um filho, Francisco Cassiano, que sendo seu arrimo marchou para a atual Campanha [...] Achando-se a Suplicante balda de recursos para poder sustentar-se e a seus dois filhos menores, recorre a V. Exa. ${ }^{85}$
\end{abstract}

Em anexo, estava uma declaração do vigário da Vitória, confirmando a veracidade da afirmação da mãe e acrescentando que "a Suplicante vive honestamente", assim salientando a ausência de um homem que lhe devia sustentação. ${ }^{86} \mathrm{O}$ interesse em uma resposta favorável talvez explique a omissão de qualquer menção a Herculano. Mais velho que Francisco Cassiano Herculano não foi à guerra e podia auxiliar a mãe. Entretanto, o vigário se calou sobre a existência dessa fonte de apoio e as autoridades, convencidas pelo pleito, deferiram o requerimento.

Nas entrelinhas do documento, percebe-se que a filha Anna não estava mais viva. Em 1867, ela teria 16 anos, ainda legalmente menor de idade e dependente da mãe para seu sustento. Contudo, os únicos filhos dependentes citados na petição da mãe foram Damiana e Jacinto. Não consegui localizar o registro de óbito de Anna, logo não fica claro se ela foi vítima das epidemias ou se morreu em outro momento. Mas essa não foi a única vez que Júlia perdeu um filho. Como vimos acima, o filho José morreu em 1849, mesmo

\footnotetext{
${ }^{84}$ Cf. Maria Júlia Ignez Soares d'Etra ao Presidente da Província, op. cit.; RODRIGUES, Marcelo Santos. Os (in)voluntários da Pátria na Guerra do Paraguai: a participação da Bahia no conflito. Dissertação de mestrado, História, Universidade Federal da Bahia, Salvador, Bahia, 2001, p. 46; 59-62.

${ }^{85}$ Maria Júlia Ignez Soares d'Etra ao Presidente da Província, op. cit.

${ }^{86}$ Maria Júlia Soares d'Etra ao Vigário da Freguesia da Vitória. Militares, Guerra de Paraguai, 1865-1869, Maço 3670, 18 nov. 1867; SOUZA, Maria Regina Santos de. Impactos da "Guerra do Paraguai" na província do Ceará (1865-1870). Dissertação de mestrado, História, Universidade Federal do Ceará, Fortaleza, Ceará, 2007, p. 141-148.
} 
ano em que nasceu. Além de Maria Pulquéria, havia outra filha chamada Maria, nascida em 1843 e batizada em 1846, mas ela não consta na tradição oral, o que sugere que faleceu pequena também.

Em algum momento durante a guerra, Francisco Cassiano foi transferido para o $54^{\circ}$ batalhão, o último da Bahia a deixar a guerra. A chegada ao Rio de Janeiro, em 24 de julho de 1870, ocasionou uma grande comemoração. Quando o $54^{\circ}$ aportou em Salvador, no dia 4 de setembro, estava à sua espera um enorme cortejo marítimo com "grande numero de saveiros embandeirados, foguetes, [e] flores". Na terra aguardava uma multidão entusiasmada, que certamente contava com a presença dos muitos veteranos que tinham chegado nos meses anteriores, entre eles os antigos zuavos.

Depois do desembarque, o batalhão assistiu à missa de ação de graças na Igreja do Bonfim, seguindo depois para o quartel do Barbalho, em que os soldados puderam reencontrar seus familiares. Para dar as boas-vindas ao "voluntário da pátria Cassiano", estava à sua espera "uma brigada de mulheres comandada pela Pulquéria, irmã do mesmo, [que] marchou em forma, dando vivas e cantarolas, até chegar no quartel". Foram acompanhadas por um músico chamado Floripes, tocador de flauta, decerto o barbeiro e músico da casa d'Etra, mencionado anteriormente. ${ }^{87} \mathrm{~A}$ "brigada de mulheres" encabeçada por Pulquéria certamente contava com filhas de santo da família, pois nessa altura o terreiro já estava funcionando.

\section{Primeiros tempos do terreiro}

De acordo com a memória oral, Francisco Cassiano era de Exu, guardião das encruzilhadas e da comunicação, mas também era do orixá guerreiro Ogum, como seu pai. Da perspectiva religiosa, esses dois eram aliados cruciais para um jovem que vivenciou cinco anos de um sangrento conflito que ceifou as vidas de cinquenta mil soldados, só contando os brasileiros. ${ }^{88}$ Quando ele chegou da guerra, o terreiro da mãe já existia e tinha certa visibilidade. O terreno se situava dentro da Fazenda Garcia, um enorme latifúndio que partia do Campo Grande para o leste, compreendendo os morros dos atuais

\footnotetext{
${ }^{87}$ Cf. RODRIGUES, Marcelo Santos. Guerra do Paraguai: os caminhos da memória entre a comemoração $e$ o esquecimento. Tese de doutorado, História Social, Universidade de São Paulo, São Paulo, São Paulo, 2009, p. 85, 101-103; O Alabama, 27 set. 1870, p. 4.

${ }^{88}$ Cf. Entrevista com Carmen Oliveira, 26/5/2016; BASTIDE, Roger. O candomblé da Bahia: rito nagô. São Paulo: Companhia das Letras, 2005, p. 165; BETHELL, Leslie. The Paraguaqan War (1864-1870). London: University of London, 1996, p. 9.
} 
bairros do Garcia e da Federação e parte dos vales no entorno, beirando o Dique do Tororó.$^{89}$ Uma parte da roça ficava no alto, próxima à Estrada do Rio Vermelho, uma antiga via que hoje, conhecida por outros nomes, ainda percorre as cumeeiras dos morros da Federação e do Engenho Velho da Federação. Outra parte acompanhava o declive da ribanceira até o riacho no vale.

Nina Rodrigues, que frequentava o terreiro nos anos 1890, já registrou o apelido Gantois, chamando atenção para a origem francesa da palavra, e observando que veio "do antigo proprietário da chácara em que [o terreiro] funciona". Estava com razão. Em 1844, a Fazenda Garcia foi comprada pela família Gantois, cujo patriarca, Edouard Gantois, belga de língua francesa, tinha se radicado na Bahia nos anos $1830 .{ }^{90}$ A família tinha negócios de vários tipos, porém, como tantos outros comerciantes da época - inclusive o ex-senhor de Júlia, como visto anteriormente - os lucros maiores vinham do tráfico de escravos. ${ }^{91}$ Os Gantois também exportavam rapé, a forma de tabaco mais apreciada pelo mercado europeu, para a França. ${ }^{92}$ A Fazenda Garcia, inclusive, foi utilizada para abrigar uma fábrica desse produto, a qual ocupava, entretanto, apenas uma pequena parte das terras. ${ }^{93}$ Aos poucos, a parte que sobrava foi fatiada em roças e arrendada ou vendida a particulares.

Esse processo começou mesmo antes da aquisição da propriedade pela família Gantois. Em 1838, a proprietária anterior, a viúva D. Joaquina Auta de Menezes e Araújo, arrendou parte das terras baixas da fazenda ao comerciante Francisco Ezequiel Meira. As terras arrendadas acompanhavam as margens do Dique do Tororó até a nascente do Rio Lucaia, continuando até a confluência do Lucaia com o Rio de São Pedro. Lá, Meira instalou um moinho de trigo movido pela força das águas, que fornecia farinha às padarias da cidade. $\mathrm{O}$ moinho passou a ser uma ponta de referência de toda a área ao redor, ainda escassamente habitada. Em meados dos anos 1860,

\footnotetext{
${ }^{89}$ Cf. APB, LN 279, fls. 15v-16v.

${ }^{90}$ Cf. RODRIGUES, Nina. O animismo fetichista dos negros baianos. Rio de Janeiro: Fundação Biblioteca Nacional, 2006 [1896], p. 51; APB, LN 279, fls. 15v-16v.

${ }^{91}$ Cf. VERGER, Pierre. Fluxo e refluxo do tráfico de escravos entre o Golfo do Benin e a Bahia de Todos os Santos, séxulos XVII-XIX. 4. ed. Salvador: Corrupio, 2002, p. 483-484; OJO, Olatunji. Letters found in the House of Kosoko, King of Lagos (1851), Introduction. African Economic History, Ann Arbor, vol. 40, 2012, p. 50; 52; Banco de Dados Slave Voyages, www.slavevoyages.org, viagens no 1468 , 2520, 2526, 3066, 3584, acessado em 5 mar. 2017.

${ }^{92}$ Cf. Saídas do dia 9. 0 Comércio, 13 set. 1843, p. 4.

${ }^{93}$ Cf. Relatório dos Trabalhos do Conselho Interino de Governo (Bahia), 1857, p. 104. Uma matéria de jornal de 1867 já falava da "casa arruinada do Moinho, à margem do Dique, na fazenda Garcia". Diário de Notícias, 6 ago. 1909, p. 6, "Ephemerides Históricas."
} 
o moinho já estava em ruínas, mas o apelido "o Moinho" para se referir à região continuou em uso por décadas. ${ }^{94} \mathrm{Na}$ parte da roça do Meira que beirava o Rio de São Pedro (que corre no vale entre os morros dos atuais bairros Garcia e Federação), havia uma mata pertencente à mesma fazenda, que "vai seguindo para trás e faz a divisão do terreno arrendado pela parte alta". Seguramente, esse terreno no alto ficava muito próximo ao local onde, de acordo com a memória oral, o terreiro de Júlia foi estabelecido por volta de 1849, em terreno arrendado por Francisco Nazareth. ${ }^{95}$

Na época de Nina Rodrigues, o Gantois era acessível por bondes que passavam no vale. Subia-se uma íngreme ladeira por degraus talhados no chão para chegar às instalações do terreiro, que ficavam "no centro de uma clareira ou roçado, sombreado de algumas árvores frondosas". A construção era humilde: paredes de taipa, coberta de telha e um piso de "solo nú e batido". ${ }^{96}$ Não encontrei registros que pudessem esclarecer a data exata de arrendamento ou da construção do barracão, mas o primeiro documento que menciona a existência de uma comunidade religiosa no local antecede os registros de Nina em trinta anos. ${ }^{97}$ Trata-se da matéria do jornal $O$ Alabama, que mencionamos na introdução deste artigo.

A matéria, datada de 4 de janeiro de 1868, reclamava de uma processão na Estrada do Rio Vermelho, protagonizada por "gente do terreiro de tia Júlia no Moinho". Evidentemente, a alcunha "Moinho" ainda predominava na linguagem popular nessa altura. A procissão contava com mais de vinte pessoas de ambos os sexos e uma banda de música de barbeiros. Júlia é citada apenas como líder do terreiro, sem referências à sua presença. Segundo o jornalista, quem estava no meio da muvuca - tão empolgada que tentara pegar um bombo para tocar também - foi "Pulqúeria, a segunda mamãe do terreiro".98 Não foi a primeira nem a última vez que ela foi citada pelo Alabama. "Pul-

\footnotetext{
${ }^{94}$ Cf. Relatório dos Trabalhos do Conselho Interino do Governo (Bahia), 1881, p. 8.

${ }^{95}$ Cf. Almanaque Político e Comercial da Cidade da Bahia, 1845, p. 251; APB, LN 260, fls. 12v-14; entrevista com Carmen Oliveira, 9/10/2016. O Rio Lucaia segue o vale da atual Avenida Vasco da Gama, enquanto o Rio de São Pedro acompanha o vale entre os morros do Garcia e da Federação.

${ }^{96}$ Cf. RODRIGUES, Nina. O animismo fetichista dos negros baianos. Rio de Janeiro: Fundação Biblioteca Nacional, 2006, p. 51-52.

${ }^{97}$ Cf. O Alabama, 4 jan. 1868, p. 6; SANTOS, Jocélio Telles dos. Menininha do Gantois: a sacralização do poder. In: SILVA, Vagner Gonçalves da (org.). Caminhos da alma. São Paulo: Selo Negro, 2002, p. 134. (Memória afro-brasileira, v. 1); PARÉS, Luis Nicolau. A formação do candomblé: história e ritual da nação jeje na Bahia. Campinas: Unicamp, 2006, p. 152. Agradeço a este último autor por compartilhar suas notas de pesquisa sobre matérias desse jornal.

${ }_{98}$ Cf. O Alabama, 4 jan. 1868, p. 6, grifos originais.
} 
quéria do Moinho" aparece em diversas matérias do jornal, sobre cerimônias de candomblé em outros terreiros e também festas do catolicismo popular.99 Aquela procissão da "gente de tia Júlia" foi caracterizada pelo Alabama como "pagode" - então sinônimo de templo pagão - e ainda como "candomblé", mas a matéria não menciona elementos sugestivos de atividade ritual. Fala-se apenas de percussão, bebida e, em certo ponto, arruaça, durante a qual o mestre da banda, um barbeiro chamado Marcos, levou uma pedrada. Outra personagem frequente nas páginas do Alabama, Marcos é sempre citado em relação às festas católicas, especialmente a do Bonfim. ${ }^{100}$ Tudo indica tratar-se de Marcos José da Silva, crioulo e dono de uma tenda de barbeiro atrás da Igreja da Sé. ${ }^{101}$ Em uma matéria, Marcos aparece como líder de uma banda, na qual entre seus integrantes constava um certo Floripes, tocador de "piston" (trompete) - sem dúvida o liberto nagô homônimo, ex-escravo de Manoel José d'Etra, que desde 1862 liderava a banda da casa d'Etra e que tocou na festa de boas-vindas quando Francisco Cassiano chegou da guerra. ${ }^{102}$

Em novembro de 1871, o terreiro de "tia Júlia" foi tema de outra matéria no Alabama, sobre a "festança do inhame novo". Durante a festa, os participantes - aparentemente todos sexo feminino - caíam "em desacordo" - ou seja, entravam em transe - e vestiam "uma tira de pano sobre os seios", provavelmente o banté, uma estreita faixa de tecido amarrada no peito de certas divindades masculinas. Para o jornalista, o ritual, de origem africana e introduzido à Bahia "pelas massas ignorantes entre nós", comemorava a safra do inhame. ${ }^{103}$ Em várias outras sociedades da África Ocidental, inclusive entre os povos iorubás, o inhame é um alimento central. Com efeito, a primeira colheita, no final da época de chuva, é motivo de um festival que começa com oferendas a divindades. No caso dos iorubás, o homenageado principal é Orixá Okó, padroeiro da agricultura e associado aos orixás caçadores. É da família funfun, o que significa que veste apenas roupa branca, como Oxalá e Oxaguiã, também louvados no festival. No candomblé da Bahia, inhame

\footnotetext{
${ }^{99}$ Cf. O Alabama, 20 jan. 1866, p. 2-3; O Alabama, 1 fev. 1868, p. 2-4; O Alabama, 16 fev. 1869, p. 2-3. Agradeço a Luis Nicolau Parés pela indicação destas matérias.

${ }^{100}$ Cf. O Alabama, 29 jan. 1870, p. 6-7; PINTO, Luiz Maria da Silva. Dicionário da língua brasileira. Ouro Preto: A Sociedade, 1832

${ }^{101}$ Cf. Almanak Administrativo, 1862, p. 400; Almanak Administrativo, 1863, p. 400; ACMS, Freg. da Sé, Óbitos 1869-1877, fl. 42v. Nos almanaques dos anos 1850, o barbeiro "Marcos Rodrigues Soares" consta com o mesmo endereço, o que leva a pensar que tratasse da mesma pessoa: cf. Almanak Administrativo, 1857, p. 371; Almanak Administrativo, 1858, p. 364.

${ }^{102}$ Cf. O Alabama, 25 jan. 1868, p. 1-2; Almanak Administrativo, 1862, p. 332.

${ }^{105}$ Cf. O Alabama, 24 nov. 1871, p. 4.
} 
é a comida predileta de todas as qualidades (avatares) de Oxalá, e inhame pilado é associado especialmente a Oxaguiã. ${ }^{104}$

Contudo, o Alabama não cita roupa branca ou qualquer outra evidência sugestiva de Oxalá ou Orixá Okó. Inclusive, a referência à faixa de tecido amarrado no peito desqualifica essa possibilidade. Tanto Oxalá quanto Okó vestem um tecido mais largo, amarrado no ombro esquerdo, num estilo chamado atakã. Ademais, menciona-se "a varíola, adorada como divindade" - uma clara referência ao orixá Omolu/Obaluaiê, dono da peste - justamente um dos orixás que usam o banté. Conhecido por vários nomes na África, entre os quais Shapanan e Sakpata, ele detém o poder sobre todas as doenças contagiosas, especialmente a varíola. Seu culto aparentemente chegou ao antigo Daomé pelos mahis e até hoje é associado a esse povo. ${ }^{105}$

Nina Rodrigues considerou Shapanan um dos orixás mais conhecidos da Bahia, comentando que "em épocas epidêmicas, a cidade apresenta-se coberta de sacrifícios". Sugerimos acima que Francisco Nazareth, por ser barbeiro, provavelmente atuava no tratamento de coléricos, recorrendo inclusive a práticas de cura de origem africana. Ademais, como Parés argumenta, o saber curativo dos barbeiros era requisitado no âmbito ritual afro-brasileiro. A origem mahi de Francisco Nazareth levanta ainda a possibilidade de que utilizasse práticas próprias ao culto a Sakpata/Shapanan. Lembremos que a tradição oral reivindica fundação em 1849, o que coincide com o início da época das epidemias e pode sugerir alguma causalidade. Na tradição oral do Gantois, porém, o único orixá associado a Francisco Nazareth é Ogum. Não fica claro, enfim, quem introduziu o culto a Omolu/Obaluaiê no terreiro e exatamente quando aconteceu, mas evidentemente foi nas primeiras décadas depois da fundação. ${ }^{106}$

\footnotetext{
${ }^{104}$ Cf. COURSEY, Donald Gilbert $\&$ COURSEY, Cecilia. The new yam festivals of West Africa. Anthropos, Ann Arbor, vol. 66, n. 3-4, 1971, p. 444-484; MACKENZIE, Peter. Hail orisha!: a phenomenology of a West African religion in the mid-nineteenth century. Leiden: Brill, 1997, p. 156-158.

${ }^{105} \mathrm{Cf}$. SOUMONNI, Elisée. Disease, religion and medicine: smallpox in nineteenth century Benin. História, Ciências, Saúde - Manguinhos, Rio de Janeiro, vol. 19, 2012, p. 35-45; VERGER, Pierre. Notas sobre o culto aos orixás e voduns. São Paulo: USP, 1999, p. 239-245.

${ }^{106}$ Cf. PARÉS, Luis Nicolau. A formação do candomblé: história e ritual da nação jeje na Bahia. Campinas: Unicamp, 2006, p. 175; PARÉS, Luis Nicolau. Milicianos, barbeiros e traficantes numa irmandade católica de africanos minas e jejes (Bahia, 1770-1830). Tempo, Niterói, vol. 20, 2014, p. 16; RODRIGUES, Nina. Os africanos no Brasil. Rio de Janeiro: Nacional, 1935, p. 339; DAVID, Onildo Reis. O inimigo invisível: epidemia na Bahia no século XIX. Salvador: UFBA, 1996, p. 85; entrevista com Carmen Oliveira, 9/10/2016.
} 
Embora o jornalista do Alabama tivesse se confundido sobre a divindade louvada na festa que assistiu, havia outra cerimônia no Gantois em que o inhame novo tinha lugar de destaque. De acordo com Querino, a festa do inhame novo era um tributo a Oxalá, um dos orixás funfun mencionados acima e associado à criação do mundo. Como em outros terreiros, o ciclo de festas para Oxalá marca a abertura do calendário ritual, iniciando-se com a lavagem do assentamento do orixá, na madrugada de uma sexta-feira, depois de uma procissão para buscar água. Esse ritual, hoje conhecido como as Águas de Oxalá, é seguido por outros dedicados às diferentes qualidades do orixá. ${ }^{107}$

Ao descrever esse conjunto de rituais, Querino destacou aquele em que “a mãe do terreiro, munida de pequeno cipó, bate nas costas das pessoas da seita". O autor chama atenção para sua função de penitência simbólica. ${ }^{108}$ Hoje, a mesma cena de castigo ritual é parte central da cerimônia pública para Oxaguiã, em que também é servido um prato de inhame pilado, comida predileta do orixá. No Gantois, essa é a primeira cerimônia do ciclo de Oxalá e acontece sempre na terceira sexta-feira de setembro. Essa época do ano, em Salvador, corresponde ao final da estação de chuvas, o que sugere preservação da antiga importância da colheita. Entretanto, há ainda outro significado no Gantois. A carta de alforria de Júlia foi emitida no dia 25 de setembro, data que, em 1840, caiu numa sexta-feira. ${ }^{109}$ Júlia era consagrada ao orixá Dadá, contudo, de acordo com Mãe Carmen, "era Oxaguiã que pegava ela". Assim, a data da festa de Oxaguiã comemora, simultaneamente, eventos dos campos sagrados e profanos: o papel desse orixá na vida religiosa de Júlia e sua passagem da escravidão para a liberdade. ${ }^{110}$

Para o antropólogo Vivaldo da Costa Lima ambos Ajagunã (isto é, Oxaguiã) e Dadá são os padroeiros do Gantois. ${ }^{111}$ Nas tradições orais de Oyó, Dadá é o irmão mais velho de Xangô. Dadá sentou no trono de Oyó duas vezes: logo antes e depois de Xangô. Na Bahia, há a mesma relação fraternal entre os dois, e Dadá é considerado uma qualidade de Xangô. De acordo com

\footnotetext{
${ }^{107}$ Para uma descrição do ciclo de Oxalá, seguramente do Ilê Axé Opô Afonjá, cf. VERGER, Pierre. Orixás. Salvador: Corrupio, 2003 [1981], p. 261-263.

${ }^{108}$ Cf. QUERINO, Manuel. Costumes africanos no Brasil. Rio de Janeiro: Civilização Brasileira, 1938, p. 55.

${ }^{109}$ Cf. APB, LN 269, fl. 48v.

${ }^{110}$ Cf. entrevista com Carmen Oliveira, 17/10/ 2013; QUERINO, Manuel. Costumes africanos no Brasil. Rio de Janeiro: Civilização Brasileira, 1938, p. 55. Na Casa Branca, em contraste, a primeira festa pública do ciclo de Oxalá é de Odudua. Na linguagem do candomblé, o verbo "pegar" é utilizado de forma coloquial para se referir ao processo de entrar em transe.

${ }^{111}$ Cf. LIMA, Vivaldo da Costa. A família de santo nos candomblés jeje-nagôs da Bahia. Salvador: Corrupio, 2003, p. 51.
} 
a tradição oral, a qualidade do santo de Júlia era Dadá Bayani Ajaká. Para Mãe Carmen, Bayani é o adereço ritual característico de Dadá: sua coroa. Verger adota a mesma perspectiva, mas Querino se refere a Bayani como orixá, também fornecendo uma detalhada descrição do assentamento dele no Gantois, em que se encontravam "três filás [ou] capacetes [...] assentados sobre marroquim de cores diversas, contendo guizos nas extremidades [e] dezesseis correias pendentes e enfeitadas de búzios". Ainda de acordo com Querino, "nos dias de festa, as filhas de santo dançam com [esses] filás na cabeça". ${ }^{12}$ Hoje, no Gantois , a festa de Dadá/Bayani encerra o ciclo de festas do terreiro. Justamente como na descrição de Querino, há uma procissão em que a coroa de Bayani é levada para o barracão, carregada na cabeça, sucessivamente, por vários filhos de santo.

Para Mãe Carmen, a posição da festa no final do calendário não é por acaso: “Nosso calendário começa com minha avó Júlia [a festa de Oxaguiã] e termina com ela [a festa de Dadá]. ${ }^{13}$ Mas, na cerimônia em louvor a Dadá, Oxaguiã tem um papel marcante. Depois da procissão com a coroa de Bayani, Oxalufã e Oxaguiã se manifestam. Em seguida, abre-se o alá (grande tecido branco, símbolo de Oxalá) que, posto para cima pelos demais participantes e pelo público, forma um toldo que cobre os orixás manifestados, enquanto os atabaques tocam o ritmo de Oxalá. Essa sequência ritual, em que louvores a Dadá cedem espaço para Oxalá, reencena a disputa espiritual entre o orixá ao qual Júlia foi consagrada e aquele que realmente descia no seu corpo.

O nome iorubá do terreiro, Ilê Axé Iyá Omi Iyamassé ("casa de axé da mãe d'água Iyamassé") tem duplo significado. Em primeiro lugar, evoca a importância dos orixás do trovão na vida de Júlia: na mitologia afro-baiana, Iyamassé é a mãe de Dadá e Xangô. Ao mesmo tempo, Iyamassé é uma qualidade de Iemanjá, orixá que, entre os egbás, ocupa um lugar fundamental, por ser a deusa do rio Ogun, que atravessa seu território. O mais importante templo de Iemanjá se encontra justamente em Abeokuta, onde Júlia morava quando foi sequestrada. Como comentamos acima, foi grande o número de egbás enviados para a escravidão atlântica, o que talvez explique, em parte, a popularidade do culto à Iemanjá na diáspora africana. Tanto no Brasil

\footnotetext{
${ }^{112}$ Cf. entrevista com Carmen Oliveira, 15/7/2016; VERGER, Pierre. Orixás. Salvador: Corrupio, 2003 [1981], p. 29; 140; VERGER, Pierre. Notas sobre o culto aos orixás e voduns. São Paulo: USP, 1999, p. 336; QUERINO, Manuel. Costumes africanos no Brasil. Rio de Janeiro: Civilização Brasileira, 1938, p. 56. Para outra abordagem de Bayani como orixá, cf. SANTOS, Deoscóredes Maximiliano dos. História de um terreiro nagô. São Paulo: Max Limonad, 1988 [1988], p. 51-52.

${ }^{113}$ Cf. entrevista com Carmen Oliveira, 17/10/2013.
} 
quanto em Cuba, ela se reconfigurou como a rainha dos oceanos, acrescentando a seu imaginário a figura da sereia, elemento da mitologia europeia desde a Antiguidade. A sereia também se tornou símbolo de outra divindade ribeirinha iorubá, Oxum. Na África, Oxum é a divindade de um rio homónimo, com templo principal em Oshogbo, mas no Brasil ela se tornou a protetora das águas doces de forma geral. ${ }^{114}$

No Gantois, até o final do século XIX, a sereia já constava como elemento iconográfico nos altares à Iemanjá e Oxum. Nina Rodrigues se refere a "duas sereias de gesso barato" que foram encomendadas do Rio de Janeiro, "uma prateada, Iemanjá, a outra dourada a bronzilho, Oxum".115 Atualmente, no sincretismo afro-católico, apenas Oxum é associada à Nossa Senhora da Conceição, mas no passado já houve uma associação semelhante com Iemanjá. ${ }^{116}$ Nesse sentido, o sobrenome "da Conceição", adotado por Júlia e sua filha Pulquéria, bem como a referência à Iyamassé, na denominação do terreiro, sugerem a importância, para elas, do culto à divindade ancestral dos egbás.

Já comentamos que o assentamento mais velho do terreiro é de Ogum, orixá de Francisco Nazareth. Os próximos altares instalados foram dos três orixás associados a Júlia: Dadá, Oxalá e Iemanjá. No mesmo período, foi estabelecido o assentamento de Oxóssi, orixá dos caçadores, ao qual Pulquéria era consagrada. Hoje em dia, a festa de Oxóssi é uma das mais importantes do terreiro. Diferentemente de outras casas, no Gantois essa cerimônia envolve uma procissão em que as filhas de santo carregam moringas cheias de flores na cabeça, conhecida como a "festa das quartinhas". Em 1902, quando a futura Mãe Menininha tinha oito anos de idade, essa procissão foi fotografada e, quatorze anos depois, foi publicada na monografia de Manuel Querino, assim se tornando a primeira imagem de um ritual de candomblé a ser veiculada num trabalho acadêmico. ${ }^{117}$

\footnotetext{
${ }^{114}$ Cf. VERGER, Pierre. Orixás. Salvador: Corrupio, 2003 [1981], p. 190-191; VERGER, Pierre. Notas sobre o culto aos orixás e voduns. São Paulo: USP, 1999, p. 100; 305; 383. Sobre a presença da sereia nas religiões afro-atlânticas, cf. DREWAL, Henry John. Mami Wata: arts for water spirits in Africa and the Americas. Los Angeles: Fowler Museum, 2008.

${ }^{115}$ Cf. RODRIGUES, Nina. Os africanos no Brasil. Rio de Janeiro: Nacional, 1935, p. 336. Provavelmente se tratam dos mesmos ícones registrados numa foto publicado por Querino, com a legenda "Cascata da Sereia", para isso cf. QUERINO, Manuel. Costumes africanos no Brasil. Salvador: Empresa Gráfica da Bahia, 1917, p. 80, Estampa XIV.

${ }^{116}$ Cf. CARNEIRO, Edison. Candomblés da Bahia. Rio de Janeiro: Civilização Brasileira, 1991 [1948], p. 67; VERGER, Pierre. Orixás. Salvador: Corrupio, 2003 [1981], p. 192.

${ }^{117}$ Cf. entrevista com Carmen Oliveira, 9/10/2016; QUERINO, Manuel. Costumes africanos no Brasil. Rio de Janeiro: Civilização Brasileira, 1938, p. 89, Estampa XVII.
} 
Segundo a tradição oral, a futura Mãe Menininha estava com dezesseis anos de idade quando sua bisavó Júlia faleceu em 1910, sendo sucedida por Pulquéria. Esta, apesar da grande impressão que deixou na memória do Gantois e no imaginário coletivo do povo de santo, ficou poucos anos no cargo, falecendo em 1918. ${ }^{118}$ A fama dessa sacerdotisa de Oxóssi, lembrada como uma mulher imponente, alta e destemida, provavelmente foi estabelecida na juventude, quando suas andanças pela cidade, em festas católicas e afro-brasileiras já chamavam a atenção dos jornalistas do Alabama. Nesse sentido, é significativo que Pulquéria, e não Júlia, foi madrinha de Menininha, iniciando-a, poucas semanas depois de batizada, ainda bebê, para Oxum.

Entre o povo de santo de Salvador de hoje, o culto aos orixás "jejes" é considerado uma antiga especialidade do Gantois em comparação a outros terreiros da nação "ketu", autodenominação utilizada pelas casas que reivindicam descendência nagô. Essa ideia é respaldada pelas diferenças nos respectivos calendários das chamadas "missas de sincretismo" do Gantois e da Casa Branca. ${ }^{119}$ Ambos os terreiros têm missas no dia de Corpus Christi (associado a Oxóssi). Entretanto, no Gantois também se celebram missas nos dias de dois santos católicos associados com orixás "jejes". No dia 26 de julho, dia de Nossa Senhora Santana, há uma missa, sempre celebrada na igreja do Rio Vermelho, dedicada a essa santa, seguida por uma festa no terreiro para o orixá Nanã Buruku. De acordo com Mãe Carmem, essa missa faz parte do calendário ritual do terreiro desde os tempos da fundadora. Uma das netas de Júlia, a mãe carnal de Menininha, era de Nanã e este orixá foi "herdado" por Cleuza, filha primogênita de Menininha. No século XX, outra missa, em homenagem a São Roque, foi acrescentada por Mãe Menininha. No dia desse santo, 17 de agosto, os filhos da casa assistem a uma missa na Igreja de São Lázaro (santo associado no sincretismo com Omolu), seguindo depois para o terreiro, quando começa uma festa para Obaluayê, associado a São Roque no sincretismo afro-baiano. ${ }^{120}$ Esses contrastes entre o calendário de missas na

\footnotetext{
${ }^{118}$ Cf. Inventário de Maria Pulqueria da Conceição Nazareth, APB, 06/2520/3020/07; ACMS, Freg. da Sé, Batismos 1889-98, fl. 56v; entrevista com Carmen Oliveira, 1/9/2013.

${ }^{119}$ Nas "missas de sincretismo", cerimônias em louvor a um determinado orixá são precedidas pela celebração de uma missa celebrada católica para o santo associado. Para uma análise do sincretismo que faz referência a esse costume, cf. SOUSA JUNIOR, Vilson Caetano de. Orixás, santos e festas. Salvador: Uneb, 2003.

${ }^{120}$ Cf. LANDES, Ruth. A cidade das mulheres. Rio de Janeiro: UFRJ, 2002, p. 279; entrevista com Carmen Oliveira, 15/7/2016. Para um estudo etnográfico recente do Gantois, cf. FLAKSMAN, Clara Mariani. Narrativas, relações e emaranhados: os enredos do candomblé no Terreiro do Gantois, Salvador,
} 
Casa Branca e no Gantois salientam a importância do legado jeje no Gantois, que seguramente evidencia a influência de Francisco Nazareth d'Etra e sua gente nos primeiros tempos do terreiro.

\section{Vínculos com outros terreiros}

Em fevereiro de 1869, o Alabama publicou uma longa matéria sobre uma cerimônia num terreiro liderado por certa Maria Velludinha. A festa, que coincidiu com os três dias do Entrudo, marcava o encerramento das atividades religiosas para a Quaresma, como ainda é comum nos terreiros mais antigos. Ao analisar essa matéria, o antropólogo Luis Nicolau Parés argumenta que outras matérias do mesmo jornal revelam uma relação estreita entre Maria Velludinha e um importante terreiro de nação jeje-mahi, o Zoogodô Bogum Malê Rundó, popularmente conhecido como o Bogum. O autor chama atenção para a presença, na festa na casa de Maria Velludinha, de dignidades de outros terreiros, entre eles a mãe de santo Ludovina Pessoa, personagem importante nos primórdios do Bogum, bem como do Seja Hundé, um terreiro jeje, em Cachoeira. Entretanto, uma das participantes mais ativas foi "Pulquéria do Moinho", que "por ser muito influída" chegou um dia antes do início das festividades. ${ }^{121}$ Evidentemente, Pulquéria tinha certa intimidade com a casa.

Essa familiaridade com o povo do jeje provavelmente começou quando seu pai ainda era vivo. As tradições orais sustentam que Francisco Nazareth estava envolvido no Bogum. No Gantois, fala-se de uma árvore plantada por ele no Bogum que abrigava o assentamento do vodum Azonodô. As memórias no Bogum concordam, com um detalhe a mais: ele teria trazido a árvore da África. ${ }^{122}$ Não encontrei evidências de viagens atlânticas realizadas por Francisco Nazareth. Contudo, por meio da casa d'Etra ele estava inserido numa rede de barbeiros africanos que tinham contato com a Costa da Mina, a começar com seu próprio padrinho, capitão de navios negreiros, e vários compadres seus, entre eles Faustino de Santa Anna e José Bernardino da Costa Farias. Portanto, mesmo que Francisco Nazareth não tivesse voltado

Bahia. Tese de doutorado, Antropologia Social, Universidade Federal do Rio de Janeiro, Rio de Janeiro, Rio de Janeiro, 2014.

${ }^{121}$ Cf. O Alabama, 16 fev. 1869, p. 2-3; PARÉS, Luis Nicolau. A formação do candomblé: história e ritual da nação jeje na Bahia. Campinas: Unicamp, 2006, p. 356; 182-190.

${ }^{122}$ Cf. Entrevista com Carmen Oliveira, 1/9/2013; PARÉS, Luis Nicolau. A formação do candomblé: história e ritual da nação jeje na Bahia. Campinas: Unicamp, 2006, p. 350-352. 
para a Costa, ele estava socialmente muito bem situado para encomendar produtos africanos, inclusive flora e fauna de importância ritual.

No que tange à relação de Júlia com a Casa Branca, as datas dos dois documentos citados logo na introdução deste texto - a matéria do Alabama, de 1868, sobre o terreiro de Júlia e a abertura do testamento de Marcelina Obatossi em 1885 - já questionam a sequência de eventos sugerida por Edison Carneiro de que o falecimento de Marcelina teria antecedido a fundação do Gantois. Ademais, como mostrado anteriormente, as tradições orais do Gantois reivindicam fundação ainda em vida de Francisco Nazareth. Isso é apoiado por evidências etnográficas daquele terreiro: o assentamento mais velho do terreiro é justamente de Ogum, o orixá de Francisco Nazareth. Ademais, como mostrado anteriormente, as tradições orais do Gantois reivindicam fundação ainda em vida de Francisco Nazareth. Isso é apoiado por evidências etnográficas daquele terreiro: o assentamento mais velho do terreiro é justamente do orixá dele, Ogum. O arrendamento, portanto, provavelmente foi antes de 1859, quando Francisco Nazareth faleceu. ${ }^{123}$

Uma análise da trajetória de um nagô liberto lembrado na Casa Branca como um dos fundadores, Bamboxê Obitikô (Rodolfo Manoel Martins de Andrade), aponta para esse mesmo período como a data da separação entre as duas comunidades. Como mostramos em outro trabalho, Bamboxê foi batizado como escravo em 1850, o que sugere que chegou ao Brasil no final dos anos 1840. Sua atuação na Casa Branca provavelmente se deu por volta de 1857, quando Marcelina Obatossi o ajudou a obter sua alforria. Tudo indica que a contribuição de Bamboxê à comunidade religiosa se deu a partir desse momento, o que certamente não corresponde à criação dos primeiros assentamentos, mas à mudança posterior do terreiro para o local atual no Engenho Velho da Federação. Na sequência de ancestrais masculinos saudados no ritual do padê da Casa Branca, Bamboxê é chamado em terceiro lugar, como Essá Obitikô. No Gantois, entretanto, apesar de ele ser reverenciado, não é como ancestral fundador, mas por ter sido importante no período formativo do candomblé de modo geral. Esse detalhe é fundamental, pois revela que sua atuação na Casa Branca foi posterior à separação entre as duas comuni-

\footnotetext{
${ }^{123}$ Cf. O Alabama, 4 jan. 1868, p. 6; CASTILLO, Lisa Earl \& PARÉS, Luis Nicolau. Marcelina da Silva da Silva e seu mundo: novos dados para uma historiografia do candomblé ketu. Afro-Ásia, Salvador, n. 36, 2007, p. 143; entrevista com Carmen Oliveira, 9/10/2016.
} 
dades, o que combina quase perfeitamente com a cronologia para a fundação do Gantois sugerida pela data de falecimento de Francisco Nazareth. ${ }^{124}$

Há outros pontos de divergência e convergência no conjunto de ancestrais das duas casas que também ajudam a desemaranhar a sequência da fragmentação da comunidade primordial. Em ambos os terreiros, um dos primeiros ancestrais masculinos é Essá Assika. Disso, infere-se que no tempo de sua atuação a cisão ainda não tinha acontecido. Em relação às ancestrais femininas, os três primeiros nomes são os mesmos em ambas as casas, mas há diferenças na ordem. Na Casa Branca, a primeira a ser saudada é Iyá Adetá, seguida por Iyá Akalá e, depois, por Iyá Nassô. No Gantois, Iyá Nassô permanece em terceiro lugar, mas a ordem das outras duas é invertida: o primeiro lugar é de Iyá Akalá, seguida por Iyá Adetá. Nesse terreiro, Iyá Akalá ainda é identificada como a "mãe" de Júlia, o que tem sido interpretado, por vezes, como um parentesco consanguíneo. Acredito, porém, que seja na verdade uma descrição de relação espiritual entre as duas, uma vez que a mãe carnal de Júlia não figura na memória de seu sequestro e que não há narrativas que falam de sua chegada à Bahia. No caso, Júlia teria sido iniciada na Bahia por Iyá Akalá. ${ }^{125}$

A ordem de chamada de ancestrais não depende da data de nascimento, mas da senioridade ritual a partir da data de iniciação ou de entrada na comunidade religiosa. Nesse sentido, a falta de consenso sobre a ordem relativa de Adetá e Akalá - a única divergência entre os dois terreiros sobre as três primeiras figuras femininas - parece respaldar a afirmação de Edison Carneiro, de que não havia certeza se essas mulheres "repartiam entre si o poder ou se sucederam nele". Contudo, ao que parece, Iyá Nassô foi a mais nova das três, na idade iniciática, uma vez que ela é chamada em terceiro lugar em ambas as casas, inclusive naquela que leva seu nome. ${ }^{126}$

\footnotetext{
${ }^{124}$ Cf. CASTILLO, Lisa Earl. Entre memória, mito e história: viajantes transatlânticos da Casa Branca. In: REIS, João José \& AZEVEDO, Elciene (org.). Escravidão e suas sombras. Salvador: UFBA, 2012, p. 87-89; VERGER, Pierre. Orixás, Salvador: Corrupio, 2003 [1981], p. 29; entrevista com Carmen Oliveira, 26/5/2016; entrevista com Areelson Antônio Conceição Chagas, 1/4/2017.

${ }^{125} \mathrm{Cf}$. Entrevistas com Carmen Oliveira, 3/9/2013, 19/10/2013; entrevista com Areelson Antônio Conceição Chagas, 1/4/2017. Menininha: a mãe de santo que o consumo não absorveu, Tribuna da Bahia, 26/2/1972; NÓBREGA, Cida \& ECHEVERRÍA, Regina. Mãe Menininha do Gantois: uma biografia. Salvador: Corrupio, 2006, p. 13. Cabe notar que em ambas as casas, Adetá é chamada durante a recitação da linhagem feminina, o que contradiz a sugestão levantada por alguns pesquisadores de que teria sido um homem.

${ }^{126}$ Cf. CARNEIRO, Edison. Candomblés da Bahia. Rio de Janeiro: Civilização Brasileira, 1991 [1948], p. 56; LIMA, Vivaldo da Costa. A família de santo nos candomblés jeje-nagôs da Bahia. Salvador: Corrupio,
} 
Os rastros documentais deixados por Júlia e Iyá Nassô, aliás, deixam claro que elas conviveram por pouco tempo na Bahia. Em novembro de 1835, quando Júlia foi batizada, provavelmente com menos de um ano na cidade de Salvador, Iyá Nassô, cujo nome lusófono era Francisca da Silva, já tinha constituído uma comunidade religiosa dedicada a Xangô, que há alguns anos funcionava em sua residência na ladeira do Carmo. Entretanto, em fevereiro daquele ano, seus filhos foram acusados e depois condenados por participação na Revolta dos Malês, o que provocou uma reviravolta na vida da mãe, que passou a ser consumida pela luta para a absolvição dos filhos. Ademais, sua casa, considerada pelas autoridades a ter sido cena de reuniões para planejar a insurreição, estava na mira da polícia, o que certamente dificultou a continuação das atividades religiosas. ${ }^{127}$

Em 1836, a pedido de Francisca da Silva/Iyá Nassô, a sentença de seus filhos foi comutada em deportação para a África, e em outubro do ano seguinte ela os seguiu, junto com seu marido, escravos e agregados - entre eles Marcelina Obatossi. No outro lado do mar, o grupo estabeleceu uma nova vida na cidade de Uidá. Tudo indica que Iyá Nassô nunca retornou ao Brasil, mas dentro de dois anos Marcelina estava de volta à Bahia, onde foi amparada pelo padrinho, o barbeiro jeje Constantino do Bonfim. ${ }^{128}$ Nesse momento, Marcelina presumivelmente se reencontrou com os membros da comunidade religiosa que não tinham seguido Iyá Nassô à África.

De acordo com Verger, Mãe Menininha afirmava que Iyá Akalá também retornou à África. ${ }^{129}$ Contudo, diante de sua importância na vida religiosa de Júlia, essa viagem provavelmente foi posterior à ida de Iyá Nassô. Não conseguimos identificar os nomes lusos de Iyá Akalá ou de Iyá Adetá, o que impossibilitou o rastreamento de suas trajetórias. No entanto, ao comparar a rede

2003, p. 77-79; SILVEIRA, Renato. O candomblé da Barroquinha: processo de constituição do primeiro terreiro baiano de keto. Salvador: Maianga, 2006, p. 391-394. Como Carneiro bem observou, o próprio nome iorubá da Casa Branca, Ilê Axé Iyá Nassô, significa "casa de axé de Iyá Nassô", o que evidencia sua grande importância na história desta comunidade.

${ }^{127}$ Cf. PARÉS, Luis Nicolau $\mathcal{E}$ CASTILLO, Lisa Earl. José Pedro Autran e o retorno de Xangô. Religião e Sociedade, Rio de Janeiro, vol. 35, n. 1, 2015, p. 22-24; CASTILLO, Lisa Earl E PARÉS, Luis Nicolau. Marcelina da Silva e seu mundo: novos dados para uma historiografia do candomblé ketu. Afro-Ásia, Salvador, n. 36, 2007, p. 119-124.

${ }^{128}$ Cf. PARÉS, Luis Nicolau $\mathcal{E}$ CASTILLO, Lisa Earl. José Pedro Autran e o retorno de Xangô. Religião e Sociedade, Rio de Janeiro, vol. 35, n. 1, 2015, p. 22-24; CASTILLO, Lisa Earl E PARÉS, Luis Nicolau. Marcelina da Silva e seu mundo: novos dados para uma historiografia do candomblé ketu. Afro-Ásia, Salvador, n. 36, 2007, p. 119-124.

${ }^{129}$ Cf. VERGER, Pierre. Orixás. Salvador: Corrupio, 2003 [1981], p. 29. 
de compadrio de Marcelina da Silva com aquela de Júlia e seu marido, identificamos dois homens que transitavam entre as duas comunidades religiosas.

Um deles foi o barbeiro nagô José Bernardino da Costa Farias, conhecido compadre de Francisco Nazareth e Júlia. José Bernardino foi escravo do mesmo senhor que o padrinho de Marcelina, Constantino do Bonfim, que fazia parte da rede sociorreligiosa de Iyá Nassô. ${ }^{130}$ Ambos Constantino e José Bernardino certamente já transitavam pela casa d'Etra por meio de seu senhor, que era amigo de José Antonio d'Etra. Sabe-se que, no contexto religioso afro-brasileiro, o apadrinhamento católico frequentemente sinalizava a criação de uma relação paralela no culto aos orixás.

Não sei se José Bernardino presenciou o batismo de Marcelina Obatossi ou sua iniciação posterior para Xangô. O certo é que até 28 de janeiro de 1844 já se conheciam bem, porque nessa data Marcelina foi madrinha de uma escrava de José Bernardino. Na mesma cerimônia, ela foi madrinha da amasiada de José Bernardino, Anna Rita, nagô e ainda cativa. ${ }^{131} \mathrm{O}$ padrinho de ambas as escravas foi Vicente Navarro, um nagô liberto envolvido em negócios marítimos com a África, junto com José Bernardino. ${ }^{132}$ Esses laços de compadrio entre José Bernardino e Marcelina antecederam, por vários anos, o compadrio formal estabelecido por ele com Júlia e seu marido entre 1851 e 1853, quando, como foi discutido acima, Francisco Nazareth apadrinhou um escravo de José Bernardino e Júlia se tornou madrinha de dois filhos que ele teve com a mesma Anna Rita.

O que parece surgir por esse intricado tecido de relações interpoladas é que José Bernardino e Constantino do Bonfim estivessem envolvidos na comunidade em que Iyá Akalá, Iyá Adetá e Iyá Nassô atuavam, o legendário

\footnotetext{
${ }^{130}$ Cf. APB, LN 228, fl. 43; Inventário de José da Costa Farias (1829), 04/1711/2181/02, fls. 4v-5; PARÉS, Luis Nicolau \& CASTILLO, Lisa Earl. José Pedro Autran e o retorno de Xangô. Religião e Sociedade, Rio de Janeiro, vol. 35, n. 1, 2015, p. 19-21; PARÉS, Luis Nicolau. Milicianos, barbeiros e traficantes numa irmandade católica de africanos minas e jejes (Bahia, 1770-1830). Tempo, Niterói, vol. 20, 2014, p. 22-23.

${ }^{131}$ Cf. ACMS, Freg. da Sé, Batismos 1829-1861, fl. 214v.

${ }^{132}$ Poucas semanas depois do batismo, em 3 mar. 1844, Vicente Antonio Navarro recebeu um passaporte para a Costa d'África. No início de 1845, quando um navio negreiro, procedente da Bahia, foi tomado próximo a Lagos por ingleses, entre os documentos encontrados a bordo foi uma carta de José Bernardino e um ex-escravo seu, Gabriel, escrita na Bahia em 30 nov. 1844, sobre negócios em andamento com Vicente Navarro. Quatro anos depois, em 2 jul. 1848, Vicente Navarro chegou de volta à Bahia, vindo do porto de Onim [Lagos], no brigue Cadet: APB, Registros de passaportes, Maço 5886; HCPP, vol. 29 (1846). Class A, no 26, Her Majesty's Commissioners to the Earl of Aberdeen, Sierra Leone, March 17, 1845, encl. 1, Report of the Case of the Esperança, p. 198; Correio Mercantil, 21 jun. 1848, p. 4.
} 
Candomblé da Barroquinha. Diante da amizade preexistente entre Francisco Nazareth e José Bernardino, parece provável, inclusive, que a aproximação de Júlia à comunidade fosse intermediada por José Bernardino e Constantino. É provável que Anna Rita, ao se tornar afilhada de Marcelina em 1844, passasse a ser sua filha de santo. Mais de dez anos depois, porém, Anna Rita e seu marido escolheram Júlia como madrinha de dois filhos, justamente no período em que a tradição oral do Gantois defende que a fundadora já tinha se afastado do Candomblé da Barroquinha. Ao que parece, diante das querelas que levaram Júlia a se afastar, Anna Rita e seu marido se aliaram ao campo dissidente.

Essas evidências, porém, são fragmentárias e seria prematuro chegar a conclusões definitivas. Sem os nomes africanos de José Bernardino da Costa Farias e Constantino do Bonfim é difícil saber se correspondem ou não a ancestrais masculinos invocados nos padês. Contudo, a coincidência aproximada entre a data da morte de Francisco Nazareth e o início da presença de Bamboxê Obitikô na Casa Branca indica que a cisão interna no Candomblé da Barroquinha que provocou o afastamento de Julia provavelmente aconteceu nos anos 1850. Apesar de Carneiro errar sobre o motivo da cisão entre as duas comunidades, ele parece ter sido correto ao afirmar que a mudança da Casa Branca para o Engenho Velho aconteceu "quase simultaneamente com a fundação do Gantois".133

\section{Considerações finais}

As trajetórias da egbá liberta conhecida hoje pelo nome Maria Júlia da Conceição e de seu marido, o barbeiro jeje Francisco Nazareth d'Etra, ilustram a complexidade das relações sociais que entrelaçavam africanos e crioulos na cidade da Bahia no século XIX, em que as distinções entre relações solidárias e clientelistas nem sempre eram nítidas. A experiência de Francisco Nazareth d'Etra como escravo de outro jeje que fazia parte da elite africana da cidade ilustra a importância das relações forjadas durante o cativeiro em delimitar os parâmetros de sua vida social, mesmo depois da liberdade. Os estudos sobre o candomblé têm focado na importância de Júlia e de sua nação nagô na história do Gantois, o que é indisputável, mas as evidências etnográficas sugerem que o papel de seu marido nos primeiros

\footnotetext{
${ }^{133}$ Cf. CARNEIRO, Edison. Candomblés da Bahia. Rio de Janeiro: Civilização Brasileira, 1948, p. 57; VERGER, Pierre. Orixás. Salvador: Corrupio, 2003 [1981], p. 29-30.
} 
tempos do terreiro foi mais importante do que a literatura etnográfica reconhece, sobretudo levando em conta sua atuação no terreiro jeje do Bogum.

Esse histórico de influências jejes no Gantois oferece um exemplo concreto de um argumento central de Luis Nicolau Parés, em seu livro $A$ formação do candomblé, sobre a existência de um substrato jeje no modelo ritual do candomblé nagô que surgiu durante o século XIX. Nesse sentido, o termo "jeje-nagô", cunhado por Nina Rodrigues e utilizado por gerações de estudiosos posteriores, parece ter especial relevância, não imaginado pelo médico maranhense tão entusiasmado pelas práticas nagôs no terreiro em que ele concentrou seus estudos. O envolvimento de Francisco Nazareth d'Etra no campo ritual também fornece novos insumos para os crescentes questionamentos sobre a relevância do paradigma do matriarcado para análises da organização social dos terreiros, especialmente para períodos anteriores ao século XX. Para parafrasear o título do livro recente de Julio Braga, a cidade, além de ser das mulheres, era também dos homens.

As convergências e divergências entre os conjuntos paralelos de ancestrais do Gantois e da Casa Branca sugerem que a cisão que resultou na fundação do Gantois provavelmente aconteceu na década de 1850. Apesar de contestar a narrativa que virou senso comum na literatura sobre o candomblé, ao mesmo tempo isso confirma um aspecto importante da tradição oral do Gantois. Aparentemente, Mãe Menininha tinha toda a razão quando disse que sua bisavó Júlia foi "irmã de santo, e não filha de santo, de Marcelina Obatossi".

\section{Referências bibliográficas}

ALVES, Marieta. Música de barbeiros. Revista Brasileira de Folclore, Rio de Janeiro, vol. 7, n. 17, 1967, p. 5-14.

ARAÚJO, Ana Lucia. Dahomey, Portugal and Bahia: King Adandozan and the Atlantic slave trade. Slavery \& Abolition, Abingdon, vol. 33, n. 1, 2012, p. 1-19.

BASTIDE, Roger. $O$ candomblé da Bahia: rito nagô. São Paulo: Companhia das Letras, 2005.

BETHELL, Leslie. The Paraguayan War (1864-1870). London: University of London, 1996.

BIOBAKU, Saburi Oladeni. The Egba and their neighbours, 1842-1872. Oxford: Clarendon Press, 1957.

BRAGA, Julio Santana. Sociedade Protetora dos Desvalidos: uma irmandade de cor. Salvador: Ianamá, 1987.

Candomblé: a cidade das mulheres e dos homens. Feira de Santana: UEFS, 2014.

BRITO, Luciana da Cruz. Temores da África: segurança, legislação e população africana na

Bahia oitocentista. Salvador: UFBA, 2016. 
BUTLER, Kim D. Freedoms given, freedoms won: Afro-Brazilians in post-abolition São Paulo and Salvador. New Brunswick: Rutgers University Press, 1998.

CARNEIRO, Edison. Candomblés da Bahia. Rio de Janeiro: Civilização Brasileira, 1991 [1948].

CASTILLO, Lisa Earl. Mapping the nineteenth-century Brazilian returnee movement: demographics, life stories and the question of slavery. Atlantic Studies, Abingdon, vol. 13, n. 1, 2016, p. 25-52.

. Bamboxê Obitikô e a expansão do culto aos orixás (século XIX): uma rede religiosa afro-atlântica. Tempo, Niterói, vol. 22, n. 39, 2016, p. 126-153.

. Entre memória, mito e história: viajantes transatlânticos da Casa Branca. In: REIS, João José $\mathcal{E}$ AZEVEDO, Elciene (org.). Escravidão e suas sombras. Salvador: UFBA, 2012, p. 65-110.

. O terreiro do Alaketu e seus fundadores: história e genealogia familiar, 1807-1867. Afro-Ásia, Salvador, n. 43, 2011, p. 213-259.

CASTILlO, Lisa Earl \& PARÉS, Luis Nicolau. Marcelina da Silva e seu mundo: novos dados para uma historiografia do candomblé ketu. Afro-Ásia, Salvador, n. 36, 2007, p. 111-151.

CHALHOUB, Sidney. Cidade febril: cortiços e epidemias na Corte Imperial. São Paulo: Companhia das Letras, 1996.

COTTA, Francis Albert. Negros e mestiços nas milícias da América portuguesa. Belo Horizonte: Crisálida, 2010.

COURSEY, Donald Gilbert $\&$ COURSEY, Cecilia. The new yam festivals of West Africa. Anthropos, Ann Arbor, vol. 66, n. 3-4, 1971, p. 444-484.

DAVID, Onildo Reis. Oinimigo invisível:epidemia na Bahia no século XIX. Salvador:UFBA, 1996.

DREWAL, Henry John. Mami Wata: arts for water spirits in Africa and the Americas. Los Angeles: Fowler Museum, 2008.

FADIPE, Nathaniel Akinremi. The sociology of the Yoruba. Ibadan: Ibadan University Press, 1970.

FARIAS, Juliana Barreto. Mercados minas: africanos ocidentais na Praça do Mercado do Rio de Janeiro (1830-1890). Rio de Janeiro: Prefeitura do Rio de Janeiro, 2015.

FARIAS, Sheila de Castro. Sinhás pretas, "damas mercadoras": as pretas minas nas cidades do Rio de Janeiro e de São João del Rey (1700-1850). Tese de livre-docência, História do Brasil, Universidade Federal Fluminense, Niterói, Rio de Janeiro, 2004.

FÉLIX JÚNIOR, Osvaldo Silva. O envio de negros da Bahia para a Guerra do Paraguai. História E Perspectivas, Uberlândia, vol. 24, n. 45, 2011, p. 379-410.

FERREIRA, Jackson André da Silva. Gurgalha: um coronel e seus dependentes no sertão baiano (Morro do Chapéu, século XIX). Tese de doutorado, História Social, Universidade Federal da Bahia, Salvador, Bahia, 2014.

FLAKSMAN, Clara Mariani. Narrativas, relações e emaranhados: os enredos do candomblé no Terreiro do Gantois, Salvador, Bahia. Tese de doutorado, Antropologia Social, Universidade Federal do Rio de Janeiro, Rio de Janeiro, Rio de Janeiro, 2014.

FRANK, Zephyr. Dutra's world: wealth and family in nineteenth-century Rio de Janeiro. Albuquerque: University of New Mexico Press, 2004. 
FRAZIER, Edward Franklin. The negro family in Bahia, Brazil. American Sociological Review, Ann Arbor, vol. 7, n. 4, 1942, p. 465-478.

GINZBURG, Carlo $\mathcal{E}$ PONI, Carlo. O nome e o como: troca desigual e mercado historiográfico. In: GINZBURG, Carlo et al. A micro-história e outros ensaios. Rio de Janeiro: Bertrand, 1989, p. 169-178.

GRAHAM, Richard. Alimentar a cidade: das vendedoras de rua à reforma liberal (Salvador, 1780-1860). São Paulo: Companhia das Letras, 2013.

JEHA, Silvana. Ganhar a vida: uma história do barbeiro africano Antônio José Dutra e sua família. Rio de Janeiro, século XIX. Revista de História, Rio de Janeiro, n. 176, 2017, p. 1-35.

JOHNSON, Samuel. The history of the Yorubas from the earliest times to the beginning of the British Protectorate. Lagos: C.S.S. Bookshops, 1969 [1921].

KRAAY, Hendrik. Os companheiros de dom Obá: os zuavos baianos e outras companhias negras na Guerra de Paraguai. Afro-Ásia, Salvador, n. 46, p. 121-161.

. Identidade nacional na política. Bahia, 1790-1840: o caso dos Henriques. In: JANCSÓ, István (org.). Brasil: formação do estado e da nação. São Paulo: Hucitec, 2003, p. 521-546.

LANDES, Ruth. A cidade das mulheres. Rio de Janeiro: UFRJ, 2002.

LARA, Silvia Hunold. Do singular ao plural - Palmares, capitães do mato e o governo dos escravos. In: REIS, João Jose \& GOMES, Flávio dos Santos. Liberdade por um fio: história dos quilombos no Brasil. São Paulo: Companhia das Letras, 1996, p. 81-109.

LAW, Robin. The Oyo Empire, c.1600-c.1836: a West African imperialism in the era of the Atlantic slave trade. Oxford: Clarendon Press, 1977.

A carreira de Francisco Félix de Souza na África Ocidental (1800-1849). Topoi, Rio de Janeiro, vol. 2, n. 2, 2001, p. 9-39.

LIMA, Vivaldo da Costa. A família de santo nos candomblés jeje-nagôs da Bahia. Salvador: Corrupio, 2003.

MABOGUNJE, Akin $\mathcal{E}$ OMER-COOPER, John. Owu in Yoruba history. Ibadan: Ibadan University Press, 1971.

MACKENZIE, Peter. Hail orisha!: a phenomenology of a West African religion in the midnineteenth century. Leiden: Brill, 1997.

MANN, Kristin. Slavery and the birth of an African City: Lagos, 1760-1900. Bloomington: Indiana University Press, 2007.

. The illegal slave trade and one Yoruba man's transatlantic passages from slavery to freedom. In: MISEVICH, Philip \& MANN, Kristin (org.). The rise and demise of slavery and the slave trade in the Atlantic world. Rochester: University of Rochester Press, 2016, p. 220-246.

MATTOSO, Kátia de Queiroz. Bahia, século XIX: uma província no Império. Rio de Janeiro: Nova Fronteira, 1992.

MATTOSO, Kátia de Queiros et al. Notas sobre as tendências ep de preços de alforria na Bahia, 1819-1888. In: REIS, João José (org.). Escravidão e invenção da liberdade: estudos sobre o negro no Brasil. São Paulo: Brasiliense, 1988, p. 60-72. 
MOTT, Luiz. Santo Antônio, o divino capitão-do-mato. In: REIS, João José E GOMES, Flávio dos Santos. Liberdade por um fio: história dos quilombos no Brasil. São Paulo: Companhia das Letras, 1996, p. 110-138.

NASCIMENTO, Anna Amélia Vieira. Dez freguesias de Salvador: aspectos sociais e urbanos do século XIX. Salvador: UFBA, 1986.

NÓBREGA, Cida E ECHEVERRÍA, Regina. Mãe Menininha do Gantois: uma biografia. Salvador: Corrupio, 2006.

OJO, Olatunji. Heepa (Hail) Orişa: The orisa factor in the birth of Yoruba identity. Journal of Religion in Africa, Ann Arbor, vol. 39, 2009, p. 36.

Letters found in the house of Kosoko, King of Lagos (1851), Introduction. African Economic History, Ann Arbor, vol. 40, 2012, p. 37-61.

OLIVEIRA, Maria Inês Cortes de. O liberto: seu mundo e os outros. São Paulo: Corrupio, 1988.

. Viver e morrer no meio dos seus: nações e comunidades africanas na Bahia do século XIX. Revista USP, São Paulo, n. 28, 1995-1996, p. 175-193.

OTERO, Solimar. Afro-Cuban diasporas in the Atlantic world. Rochester: University of Rochester Press, 2013.

PARÉS, Luís Nicolau. A formação do candomblé: história e ritual da nação jeje na Bahia. Campinas: Unicamp, 2006.

Milicianos, barbeiros e traficantes numa irmandade católica de africanos minas e jejes (Bahia, 1770-1830). Tempo, Niterói, vol. 20, 2014, p. 1-32.

PARÉS, Luis Nicolau \& CASTILLO, Lisa Earl. José Pedro Autran e o retorno de Xangô. Religião e Sociedade, Rio de Janeiro, vol. 35, n. 1, 2015, p. 13-43.

PAYNE, John Augustus Otonba. Table of principal events in Yoruba history. Lagos: Andrew M. Thomas, 1893.

PIMENTA, Tânia Salgado. Barbeiros-sangradores e curandeiros no Brasil (1808-1828). História, Ciências, Saúde - Manguinhos, Rio de Janeiro, vol. 5, n. 2, 1998, p. 349-372.

PINTO, Luiz Maria da Silva. Dicionário da língua brasileira. Ouro Preto: A Sociedade, 1832.

QUERINO, Manuel. A raça africana e seus costumes na Bahia. Salvador: Empresa Gráfica da Bahia, 1917.

. Costumes africanos no Brasil. Rio de Janeiro: Civilização Brasileira, 1938.

REGINALDO, Lucilene. Irmandades e devoções de africanos e crioulos na Bahia setecentista: histórias e experiências atlânticas. Stockholm Review of Latin American Studies, Stockholm, n. 4, 2009, p. 25-35.

Os rosários dos angolas: irmandades de africanos e crioulos na Bahia setecentista. São Paulo: Alameda, 2011.

REIS, Isabel Cristina Ferreira dos. A família negra no tempo da escravidão: Bahia, 18501888. Tese de doutorado, História, Universidade Estadual de Campinas, Campinas, São Paulo, 2007.

REIS, João José. Rebelião escrava no Brasil: a história do levante dos malês em 1835. $2^{\mathrm{a}}$ ed. São Paulo: Companhia das Letras, 2003.

A morte é uma festa: ritos fúnebres e revolta popular no Brasil do século XIX. São Paulo: Companhia das Letras, 1991. 
. Domingos Sodré, um sacerdote africano: escravidão, liberdade e candomblé na Bahia do século XIX. São Paulo: Companhia das Letras, 2008.

Escravos donos de escravos na Bahia oitocentista. Texto apresentado no seminário do grupo de pesquisa Escravidão e a Invenção da Liberdade, Universidade Federal da Bahia, maio de 2013.

. Divining slavery and freedom: the story of Domingos Sodré, an African priest in nineteenth-century Brazil. New York: Cambridge University Press, 2015.

. De escravo a rico liberto: a trajetória do africano Manoel Joaquim Ricardo na Bahia oitocentista. Revista de História da USP, São Paulo, n. 174, 2016, p. 15-68.

RODRIGUES, Jaime. De costa a costa: escravos, marinheiros e intermediários do tráfico negreiro de Angola ao Rio de Janeiro (1780-1860). São Paulo: Companhia das Letras, 2005.

RODRIGUES, Marcelo Santos. Guerra do Paraguai: os caminhos da memória entre a comemoração e o esquecimento. Tese de doutorado, História Social, Universidade de São Paulo, São Paulo, São Paulo, 2009.

. Os (in)voluntários da Pátria na Guerra do Paraguai: a participação da Bahia no conflito. Dissertação de mestrado, História, Universidade Federal da Bahia, Salvador, Bahia, 2001.

RODRIGUES, Nina. Os africanos no Brasil. Rio de Janeiro: Nacional, 1935.

. O animismo fetichista dos negros baianos. Rio de Janeiro: Fundação Biblioteca Nacional, 2006 [1896].

RUSSELL-WOOD, Anthony John. Slavery and freedom in colonial Brazil. Oxford: Oneworld, 2002.

Fidalgos and philanthropists: the Santa Casa da Misericórdia da Bahia, 1550-1755. Berkeley: University of California Press, 1968.

SAMPAIO, Consuelo Novaes. 50 anos de urbanização: Salvador da Bahia no século XIX. Salvador: Odebrecht, 2005.

SILVEIRA, Renato. O candomblé da Barroquinha: processo de constituição do primeiro terreiro de ketu. Salvador: Maianga, 2006.

SANTOS, Deoscóredes Maximiliano dos. História de um terreiro nagô. São Paulo: Max Limonad, 1988 [1962].

SANTOS, Jocélio Teles dos. Menininha do Gantois: a sacralização do poder. In: SILVA, Vagner Gonçalves da (org.). Caminhos da alma. São Paulo: Selo Negro, 2002, p. 133-152. (Memória afro-brasileira, vol. 1).

SANTOS, Juana Elbein dos. Os nagô e a morte: Padê, àsèsè e o culto egun na Bahia. Belo Horizonte: Vozes, 2002.

SCOTT, Rebecca E HÉBRARD, Jean. Provas de liberdade: uma odisseia atlântica na era da emancipação. Campinas: Unicamp, 2014.

SILVA JUNIOR, Carlos Francisco da. Slave trade, ethnicity and cultural exchanges between Bahia and the Bight of Benin, 1721-1817. Tese de doutorado, História, University of Hull, Hull, Reino Unido, 2017.

SOUSA JUNIOR, Vilson Caetano de. Orixás, santos e festas. Salvador: Uneb, 2003. 
SOUZA, Maria Regina Santos de. Impactos da "Guerra do Paraguai" na província do Ceará (1865-1870). Dissertação de mestrado, História, Universidade Federal do Ceará, Fortaleza, Ceará, 2007.

SOARES, Carlos Eugênio Líbano. Sacramento ao pé do mar: batismo de africanos na freguesia da Conceição da Praia Grande, 1700-1751. Revista de Estudos Afro- $A$ mericanos, Rio de Janeiro, vol. 1, n. 1, 2011, p. 65-88.

SOARES, Mariza de Carvalho. Trocando galanterias: a diplomacia do comércio de escravos, Brasil-Daomé, 1810-1812. Afro-Ásia, Salvador, n. 49, 2014, p. 229-227.

. African barbers in Brazilian slave ports: a case study from Rio de Janeiro. In CAÑIZARES-ESGUERRA, Jorge et al (org.). The black urban Atlantic in the age of the slave trade. Filadélfia: University of Pennsylvania Press, 2013, p. 207-230.

. O império de Santo Elesbão na cidade do Rio de Janeiro, no século XVIII. Topoi, Rio de Janeiro, 2002, p. 59-83.

Devotos da cor: identidade étnica, religiosidade e escravidão no Rio de Janeiro, século XVIII. Rio de Janeiro: Civilização Brasileira, 2000.

SOUMONNI, Elisée. Disease, religion and medicine: smallpox in nineteenth-century Benin. História, Ciências, Saúde - Manguinhos, Rio de Janeiro, vol. 19, 2012, p. 35-45.

SOUZA, Juliana Beatriz de Almeida. Virgem imperial: Nossa Senhora e o império marítimo português. Luso-Brazilian Review, Ann Arbor, vol. 45, n. 1, 2008, p. 30-52.

VAINFAS, Ronaldo. Santo Antônio na América portuguesa: religiosidade e política. Revista USP, São Paulo, n. 57, 2003, p. 28-37.

VANSINA, Jan. Oral tradition as history. Oxford: James Currey, 1985.

VERGER, Pierre. Orixás. Salvador: Corrupio, 2003 [1981].

. Fluxo e refluxo do tráfico de escravos entre o Golfo do Benin e a Bahia de Todos os Santos, séculos XVII-XIX. 4. ed. Salvador: Corrupio, 2002.

. Notas sobre o culto aos orixás e voduns. São Paulo: USP, 1999. 